AperTO - Archivio Istituzionale Open Access dell'Università di Torino

\title{
Length-dependent toxicity of TiO2 nanofibers: mitigation via shortening
}

\section{This is the author's manuscript}

Original Citation:

\section{Availability:}

This version is available http://hdl.handle.net/2318/1720841

since 2020-08-12T14:42:18Z

Published version:

DOI:10.1080/17435390.2019.1687775

Terms of use:

Open Access

Anyone can freely access the full text of works made available as "Open Access". Works made available under a Creative Commons license can be used according to the terms and conditions of said license. Use of all other works requires consent of the right holder (author or publisher) if not exempted from copyright protection by the applicable law. 


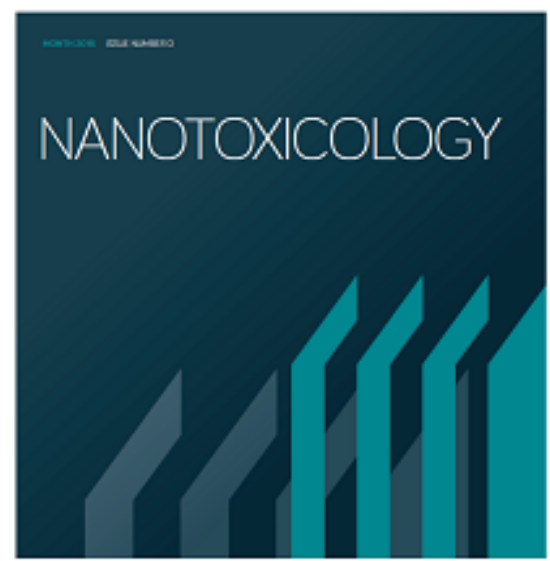

\section{Length Dependent Toxicity of $\mathrm{TiO}_{2}$ Nanofibers: Mitigation via Shortening}

\begin{tabular}{|c|c|}
\hline Journal: & Nanotoxicology \\
\hline Manuscript ID & TNAN-2019-OR-0129 \\
\hline Manuscript Type: & Original Article \\
\hline $\begin{array}{r}\text { Date Submitted by the } \\
\text { Author: }\end{array}$ & 19-Apr-2019 \\
\hline Complete List of Authors: & $\begin{array}{l}\text { Bianchi, Massimiliano; University of Parma, Department of Medicine and } \\
\text { Surgery } \\
\text { Campagnolo, Luisa; University of Rome Tor Vergata, Department of } \\
\text { Biomedicine and Prevention } \\
\text { Allegri, Manfredi; University of Parma, Department of Medicine and } \\
\text { Surgery } \\
\text { Ortelli, Simona; National Research Council of Italy, Institute of Science } \\
\text { and Technology for Ceramics (CNR-ISTEC) } \\
\text { Blosi, Magda; National Research Council of Italy, Institute of Science and } \\
\text { Technology for Ceramics (CNR-ISTEC) } \\
\text { Chiu, Martina; University of Parma, Department of Medicine and Surgery } \\
\text { Taurino, Giuseppe; University of Parma, Department of Medicine and } \\
\text { Surgery } \\
\text { Pietroiusti , Antonio; University of Rome Tor Vergata, Department of } \\
\text { Biomedicine and Prevention } \\
\text { Costa, Anna; National Research Council of Italy, Institute of Science and } \\
\text { Technology for Ceramics (CNR-ISTEC) } \\
\text { Poland, Craig; University of Edinburgh, Centre for Inflammation } \\
\text { Research } \\
\text { Baird, Daniel; University of Edinburgh, Centre for Inflammation Research } \\
\text { Duffin, Rodger; University of Edinburgh, Centre for Inflammation } \\
\text { Research } \\
\text { Bussolati, Ovidio; University of Parma, Department of Medicine and } \\
\text { Surgery }\end{array}$ \\
\hline
\end{tabular}




\begin{tabular}{|c|c|}
\hline & $\begin{array}{l}\text { Bergamaschi, Enrico; University of Turin, Department of Public Health } \\
\text { Science and Pediatrics }\end{array}$ \\
\hline Keywords: & macrophages, nanofibers, safety by design, titanium, aspect ratio \\
\hline Abstract: & 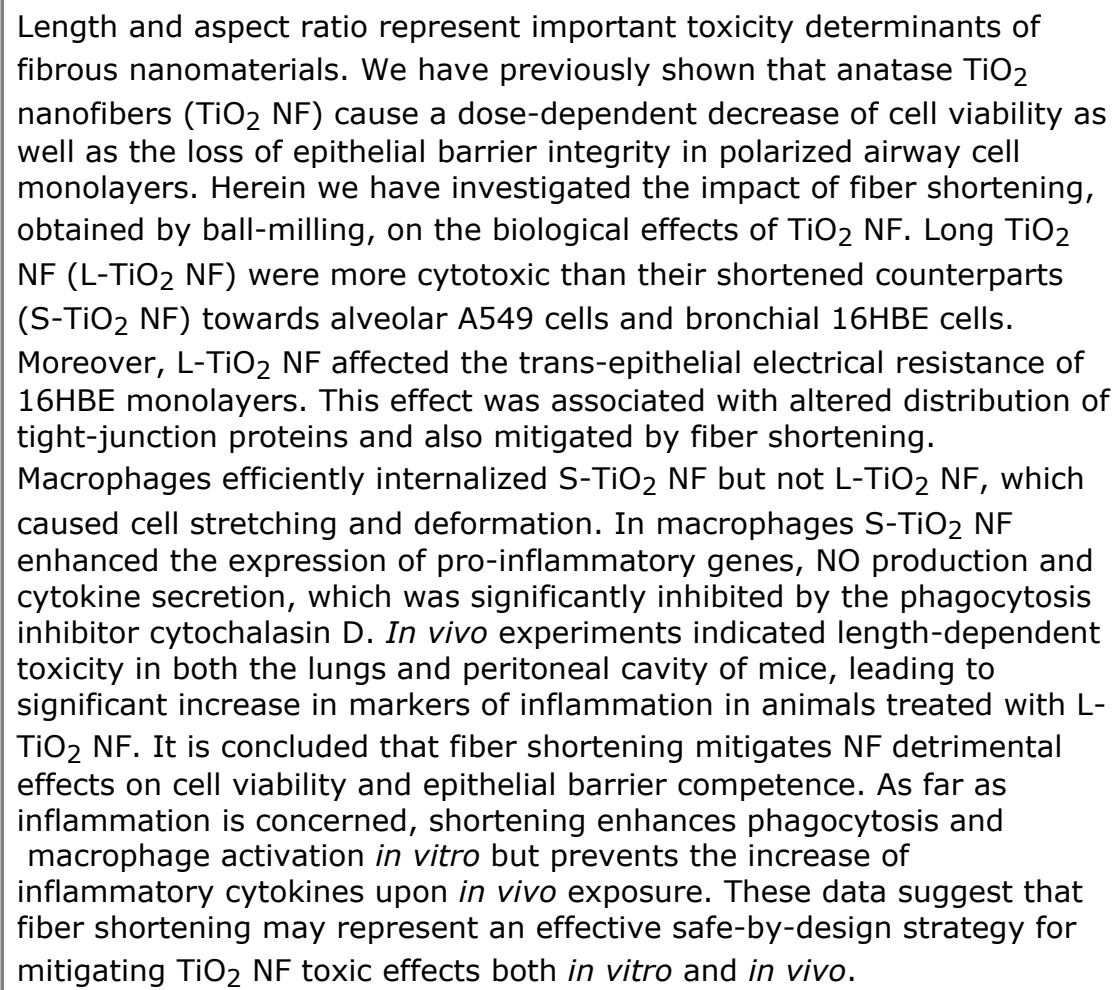 \\
\hline
\end{tabular}

\section{SCHOLARONE
Manuscripts}




\section{Length Dependent Toxicity of $\mathrm{TiO}_{2}$ Nanofibers: Mitigation via Shortening}

Massimiliano G. Bianchia, Luisa Campagnolo ${ }^{\mathrm{b}}$, Manfredi Allegria, Simona

Ortellic, Magda Blosic, Martina Chiu ${ }^{\mathrm{a}}$, Giuseppe Taurino ${ }^{\mathrm{a}}$, Antonio

Pietroiusti ${ }^{b}$, Anna L. Costa ${ }^{c}$, Craig A. Poland ${ }^{e}$, Daniel Bairde, Rodger

Duffin $^{e}$, Ovidio Bussolatia*, \& Enrico Bergamaschi ${ }^{f}$

${ }^{a}$ Department of Medicine and Surgery, University of Parma, Parma, Italy; ${ }^{b}$ Department of Biomedicine and Prevention, University of Rome Tor Vergata, Rome, Italy; 'cISTECCNR, Institute of Science and Technology for Ceramics - National Research Council of Italy, Faenza, RA, Italy; 'Centre for Inflammation Research, Queen's Medical Research Institute, The University of Edinburgh, Edinburgh, UK; ${ }^{\circ}$ Department of Public Health Science and Pediatrics, University of Turin, Turin,

Corresponding Author:

Ovidio Bussolati ovidio.bussolati@unipr.it Laboratory of General Pathology, Department of Medicine and Surgery, University of Parma, via Volturno 39, 43125 Parma (Italy) 


\section{A mitigation strategy for the toxicity of $\mathrm{TiO}_{2}$ nanofibers: high aspect ratio reduction}

Length and aspect ratio represent important toxicity determinants of fibrous nanomaterials. We have previously shown that anatase $\mathrm{TiO}_{2}$ nanofibers $\left(\mathrm{TiO}_{2} \mathrm{NF}\right)$ cause a dose-dependent decrease of cell viability as well as the loss of epithelial barrier integrity in polarized airway cell monolayers. Herein we have investigated the impact of fiber shortening, obtained by ball-milling, on the biological effects of $\mathrm{TiO}_{2} \mathrm{NF}$. Long $\mathrm{TiO}_{2} \mathrm{NF}\left(\mathrm{L}-\mathrm{TiO}_{2} \mathrm{NF}\right)$ were more cytotoxic than their shortened counterparts $\left(\mathrm{S}-\mathrm{TiO}_{2}\right.$ NF) towards alveolar A549 cells and bronchial 16HBE cells. Moreover, $\mathrm{L}_{-} \mathrm{TiO}_{2} \mathrm{NF}$ affected the trans-epithelial electrical resistance of 16HBE monolayers. This effect was associated with altered distribution of tight-junction proteins and also mitigated by fiber shortening. Macrophages efficiently internalized $\mathrm{S}^{-\mathrm{TiO}_{2}} \mathrm{NF}$ but not $\mathrm{L}-\mathrm{TiO}_{2} \mathrm{NF}$, which caused cell stretching and deformation. In macrophages $\mathrm{S}^{-\mathrm{TiO}_{2}} \mathrm{NF}$ enhanced the expression of pro-inflammatory genes, NO production and cytokine secretion, which was significantly inhibited by the phagocytosis inhibitor cytochalasin B. In vivo experiments indicated length-dependent toxicity in both the lungs and peritoneal cavity of mice, leading to significant increase in markers of inflammation in animals treated with $\mathrm{L}_{-} \mathrm{TiO}_{2} \mathrm{NF}$. It is concluded that fiber shortening mitigates NF detrimental effects on cell viability and epithelial barrier competence in vitro as well as the increase of inflammatory cytokines and granulocytes influx upon in vivo exposure. These data suggest that fiber shortening may represent an effective safe-by-design strategy for mitigating $\mathrm{TiO}_{2} \mathrm{NF}$ toxic effects both in vitro and in vivo.

Keywords: aspect ratio; macrophages; nanofibers; safety-by-design; titanium dioxide

\section{Introduction}

High aspect ratio nanostructures (HARN) such as nanotubes, nanofibers, nanowires, are increasingly used, either pure or in composites, in many industrial applications, such as electronics and photovoltaics. However, whilst nanofibers continue to show their utility in many applications, the morphological similarity of these materials to pathogenic 
fibers such as asbestos still represents a serious concern about the potential health implications of exposure. This association, based on morphology, relies upon the structure-activity relationship, known as the "fiber pathogenicity paradigm" (FPP), which identifies three critical features that are required for a fibrous particle to present a fiber-type health hazard: i) aspect ratio and length (dimension), ii) persistence of a particle in the biological environment and its resistance to breakage and dissolution (durability) and, most crucially for consideration of risk, iii) the exposure to the particle in question (dose) (Donaldson and Tran, 2004). Dimension, durability and dose, or the 3 Ds, provide the cornerstone of the FPP and have been reviewed alongside other determinants of particle-induced toxicity (Donaldson et al., 2011, Donaldson and Poland, 2013, Donaldson et al., 2013).

The focus of this study is the role of length in the pathogenicity of $\mathrm{TiO}_{2}$ nanofibers $\left(\mathrm{TiO}_{2} \mathrm{NF}\right)$. The role of length in fiber pathogenicity, originally proposed by Stanton (Stanton et al., 1977) and applied to more recent evaluations of nanofibers (Schinwald et al., 2012a), is in part reflected by the World Health Organisation which defines a minimum length and aspect ratio ( $5 \mu \mathrm{m}$ and 3:1, respectively) for respirable fibers. Over the years, numerous experimental studies have investigated in vivo the contribution of length to fiber toxicity by either comparing samples containing different proportions of long mineral fibers (Davis et al., 1991) or modifying their length (e.g. via ball milling) to assess the impact on toxicity (Kuschner and Wright, 1976, Davis et al., 1986b, Davis and Jones, 1988, Donaldson et al., 1989, Goodglick and Kane, 1990). Those studies have usually found that fiber shortening causes mitigation or, in some cases, virtual absence of toxicity.

Although the application of these conclusions to the biological effects of nanomaterials 
has been under scrutiny, most studies indicate that length and aspect ratio are important toxicity determinants also for nanofibers (Poland et al., 2008b, Rotoli et al., 2009, Poland et al., 2011, Ji et al., 2012, Schinwald et al., 2012b), with long fibers exerting higher toxicity than shorter ones. A challenge in these studies is the needing of comparing long and short versions of the same material that ideally differ only in terms of length instead of comparing two separate samples obtained from different sources (e.g. batches, processes or manufacturers).

One of the few studies that addresses this issue concerns laboratory-made $\mathrm{TiO}_{2}$ nanobelts of different length (Hamilton et al., 2009). $\mathrm{TiO}_{2} \mathrm{HARN}$, either pure or as composite components, are increasingly used in a variety of fields in the form of nanotubes, nanofibers or nanobelts. Although the toxic properties of each form have not been characterized in detail, $\mathrm{TiO}_{2}$ nanobelts have been described to cause cytotoxicity in vitro, inflammasome activation and airway inflammation after respiratory exposure, (Hamilton et al., 2009, Xia et al., 2013, Hamilton et al., 2014, Tilton et al., 2014, Jessop et al., 2017). Short nanobelts have been described to exert milder toxic effects than longer ones (Hamilton et al., 2009, Porter et al., 2013). Recently, some information on the effects of $\mathrm{TiO}_{2}$ nanofibers after oral administration in vivo has been also provided (Gato et al., 2017, Bartel et al., 2018, Hunter et al., 2018), indicating that mild renal and hepatic toxicity is detected along with an increased expression of genes involved in immunity and inflammation, although these studies did not assess the relationship between fiber length and biological effects. We have recently characterized the toxic properties of $\mathrm{TiO}_{2}$ nanofibers of industrial origin (Allegri et al., 2016a), finding that, at in vitro doses $\left(10 \mu \mathrm{g} / \mathrm{cm}^{2}\right)$ corresponding to high, but plausible, human equivalent exposures $\left(29.3 \mathrm{mg} / \mathrm{m}^{3}\right)$, a significant cytotoxic effect was detected in murine macrophages. 
Those results prompted us to evaluate whether fiber shortening mitigates $\mathrm{TiO}_{2} \mathrm{NF}$ toxicity. In particular, we studied the biological effects of long and shortened $\mathrm{TiO}_{2} \mathrm{NF}$, investigating their effects on epithelial barrier function and macrophage activation in vitro as well as on airway secretion of cytokines upon respiratory exposure in vivo. Furthermore, we have also investigated the acute inflammatory effects of these materials in the peritoneal cavity, used here as a surrogate for the pleural space and mesothelial cell exposure. This model has been used widely to investigate fiber-type toxicity of amosite asbestos fibers (Davis et al., 1986a) as well as of fibrous nanomaterials (Poland et al., 2008a, Poland et al., 2011).

\section{Materials and methods}

\subsection{Preparation, characterization and dispersion of the materials}

Titanium dioxide nanofibers (Long fibers, $\mathrm{L}-\mathrm{TiO}_{2} \mathrm{NF}$ ) obtained through electrospinning, were supplied by Elmarco, Liberec, (Czech Republic). The characteristics of $\mathrm{L}_{-} \mathrm{TiO}_{2} \mathrm{NF}$ have been described by Allegri et al. (Allegri et al., 2016a).

For fiber shortening, the $\mathrm{TiO}_{2} \mathrm{NF}$ were suspended in distilled water and subjected to ball milling using $\mathrm{ZrO}_{2}$ spheres for $15 \mathrm{~h}$. In order to control size homogenization of to favor the milling process, grinding media with different diameters were used (50 wt $\%$ $\mathrm{ZrO}_{2}$ spheres with $3 \mathrm{~mm}$ diameter and $50 \mathrm{wt} \% \mathrm{ZrO}_{2}$ spheres with $5 \mathrm{~mm}$ diameter). No release of $\mathrm{Zr}$ occurred during the milling process, as assessed with ICP analysis.

Both L- and ball-milled $\mathrm{TiO}_{2}$ nanofibers (Short fibers, $\mathrm{S}-\mathrm{TiO}_{2} \mathrm{NF}$ ) were dispersed at 3 $\%(\mathrm{wt})$ in a colloidal suspension (distilled water, $\mathrm{pH}=3.8$ ) and characterized as described in our previous work (Allegri et al., 2016a). Characteristics are summarized in Table 1. Aliquots of NF colloidal suspensions were incubated at $40^{\circ} \mathrm{C}$, till a complete 
evaporation of the water. After that, $\mathrm{L}-$ and $\mathrm{S}-\mathrm{TiO}_{2} \mathrm{NF}$ were put in glass tubes and heated at $240^{\circ} \mathrm{C}$ for $4 \mathrm{~h}$ to obtain sterile, LPS-free powders.

Zeta-potential was determined by electrophoretic light scattering (ELS) measurements using Zetasizer Nanoseries apparatus (Malvern Instruments, Malvern, UK) on both (Land $\left.\mathrm{S}_{-} \mathrm{TiO}_{2} \mathrm{NF}\right) 1 \mathrm{~g} / \mathrm{L}$ nanosuspensions, diluting with distilled water.

The investigation of the nanofiber size distribution was performed by scanning electron microscopy using FE-SEM (Carl Zeiss Sigma NTS Gmbh, Öberkochen, Germany). Nanofibers were dispersed on a standard aluminum support by dripping the diluted prepared nanosuspensions. Samples were dried in air and then treated at $100^{\circ} \mathrm{C}$ for 5 minutes to ensure the complete evaporation of water before FE-SEM analysis. Image analysis (ImageJ, Wayne Rasband, 1997) was performed on more than 150 nanofibers to calculate the average diameters, lengths and standard deviation of $\mathrm{TiO}_{2} \mathrm{NF}$ samples. NF were then suspended, according to a slightly modified Nanogenotox protocol in a solution of $0.05 \%$ Bovine Serum Albumin (BSA, Sigma Aldrich, Milan, Italy) in Phosphate Buffered Saline without calcium and magnesium (PBS) to obtain 50x suspensions of the highest dose tested on cells $\left(80 \mu \mathrm{g} / \mathrm{cm}^{2}\right)$. After vortex mixing (30 sec) and water bath sonication (10 min, $400 \mathrm{~W}$ with a Branson 5510$)$, the stock suspensions were subsequently diluted in the same solvent to obtain 50x stocks of the other doses.

The multiwalled carbon nanotubes NM-401 (JRC Repository, Ispra, Varese, Italy) were used as a positive benchmark material (Allegri et al., 2016b) and treated as the NF. Amosite asbestos was enriched for long fiber component to create the long fiber amosite asbestos (LFA) sample of which $50.36 \%$ fibres $>15 \mu \mathrm{m}$ and $35.25 \%$ fibres $>20 \mu \mathrm{m}$ as previously determined (Poland et al., 2008b). A sub-aliquot of LFA was ball milled, 
pulverizing the long fibers to produce a short fiber amosite (SFA) fraction as previously described (Davis et al., 1986a) with $4.46 \%$ fibres $>15 \mu \mathrm{m}$ and $0.99 \%$ fibres $>20 \mu \mathrm{m}$.

\subsection{Cell culture}

For the in vitro experiments we used mouse peritoneal monocyte-macrophage Raw 264.7 cells, human alveolar carcinoma epithelial cells A549 and human normal immortalized 16HBE bronchial cells. Both Raw 264.7 and A549 cell lines were obtained from the Cell Bank of the IZSLER (Istituto Zooprofilattico Sperimentale della Lombardia e dell'Emilia-Romagna, Brescia, Italy), while 16HBE cells were kindly provided by Prof. Peter Hoet (University of Leuven, Belgium). Raw 264.7 cells were cultured in Dulbecco's modified Eagle's medium (DMEM) supplemented with 10\% Fetal Bovine Serum (FBS), 4 mM glutamine, and antibiotics (streptomycin $100 \mu \mathrm{g} / \mathrm{mL} /$ penicillin, $100 \mathrm{U} / \mathrm{mL}$ ), while A549 cells were cultured in F-12 Ham's medium supplemented with 10\% FBS, $1 \mathrm{mM}$ glutamine, and antibiotics. $16 \mathrm{HBE}$ cells were grown in DMEM/F12 (1:1) supplemented with 5\% of FBS, 2 mM glutamine and antibiotics. All cultures were maintained in a humidified atmosphere of $5 \% \mathrm{CO}_{2}$ in air in $10-\mathrm{cm}$ dishes.

\subsection{Cell viability}

For cell viability analysis, both A549 and $16 \mathrm{HBE}$ cells were seeded in complete growth medium at a density of $3.1 \times 10^{4}$ cells $/ \mathrm{cm}^{2}$ in $96-$ well plates (Falcon, Corning Inc., Corning, NY, USA). After $24 \mathrm{~h}$ in culture, growth medium was replaced with fresh medium supplemented with the materials (dose range from 20 to $80 \mu \mathrm{g} / \mathrm{cm}^{2}$ ). Vehicle $(0.05 \%$ BSA in PBS) was added to the control cells at the same dilution used for treatment with NF. Cell viability was tested (O'Brien et al., 2000) replacing medium with a solution of resazurin $(44 \mu \mathrm{M})$ in serum-free medium, after 24,48 and $72 \mathrm{~h}$ of 
incubation with the materials. Fluorescence was measured at $572 \mathrm{~nm}$ with a multimode plate reader Enspire (Perkin Elmer, Waltham, MA, USA). Possible interference of the materials with the test was assessed incubating the dye in the presence of the materials at the highest dose tested. In the absence of cells, no fluorescence signal was detected above the background.

\subsection{Nitrite medium concentration}

Nitrite concentration, as a proxy for NO production, was determined as described in Bianchi et al. (Bianchi et al., 2015). Briefly, after treatments, $100 \mu 1$ of medium were transferred to black 96-well plates with a clear bottom (Corning, Corning, NY, USA). $20 \mu \mathrm{l}$ of a solution of 2,3-diaminonaphthalene (DAN, $0.025 \mathrm{mg} / \mathrm{ml}$ in $0.31 \mathrm{M} \mathrm{HCl}$ ) were then added to the media and, after 10 min at RT, the reaction was stopped with $20 \mu \mathrm{l}$ of 0.7 $\mathrm{M} \mathrm{NaOH}$. Standards were performed in the same medium from a solution of $1 \mathrm{mM}$ sodium nitrite. Fluorescence was determined with a multimode plate reader Perkin Elmer Enspire

\subsection{Trans-Epithelial Electric Resistance (TEER) and permeability}

For these experiments, 16HBE cells were seeded into cell culture inserts with membrane filters (pore size $0.4 \mu \mathrm{m}$ ) for Falcon 24-well-multitrays (Becton, Dickinson \& Company, Franklin Lakes, NJ, USA) at a density of $10 \times 10^{4}$ cells $/ \mathrm{cm}^{2}$, and grown for $4 \mathrm{~d}$ until a tight monolayer was formed (TEER $>1000 \Omega / \mathrm{cm}^{2}$ ). Materials were then added in the apical chamber without changing the medium, and TEER was measured at the indicated times of treatment. Every $3 \mathrm{~d}$ from NF supplementation, $100 \mu 1$ and $300 \mu 1$ of culture medium were replaced with fresh medium in the apical and basolateral side, respectively. TEER changes were expressed as the percentage of the initial value adjusted for control cell monolayers according to Equation 1 (Salem et al., 2009): 


\section{Final TEER (treated)}

$\% \triangle T E E R=$
Initial TEER (treated)

$\mathrm{x}$

Final TEER (control) Initial TEER ${ }_{(\text {control })}$

x $100(1)$

At the end of the incubation (19d of treatment) monolayers were used for the determination of viability, incubating cells with resazurin from the apical side, and fluorescein permeability, adding the fluorescent dye (Fluorescein di-sodium salt, MW 376,27, Sigma-Aldrich F6377, $5 \mu \mathrm{M}$ ) at the apical side and measuring the fluorescence in the baso-lateral medium after $30 \mathrm{~min}$.

\subsection{RT-PCR}

Total RNA was isolated from Raw 264.7 cells with GenElute Mammalian Total RNA Miniprep Kit (Sigma-Aldrich). After reverse transcription, aliquots of cDNA from each sample were amplified in a total volume of $25 \mu \mathrm{l}$ with Go Taq PCR Master Mix (Promega, Italia, Milan, Italy), along with the forward and reverse primers (5 pmol each) reported in Table 1. Real time PCR was performed in a 36-well RotorGeneTM3000, version 5.0.60 (Corbett Research, Mortlake, Australia). For all the cDNA to be quantified, each cycle consisted of a denaturation step at $95{ }^{\circ} \mathrm{C}$ for $20 \mathrm{~s}$, followed by separate annealing (30s) and extension (30s) steps at a temperature characteristic for each pair of primers (Table 1). Fluorescence was monitored at the end of each extension step. At the end of the amplification cycles, a melting curve analysis was added. Data analysis was made according to the relative standard curve method (Bustin, 2000), while cDNA abundance was expressed as the ratio between each investigated cDNA and Gapdh cDNA.

\subsection{Confocal microscopy}

For the evaluation of NF internalization, confocal microscopy of fixed Raw264.7 cells 
was performed as previously described with minor modifications (Bianchi et al., 2015). Raw264.7 cells were seeded on four-chamber slides at a density of $15 \times 10^{4}$ cells $/ \mathrm{cm}^{2}$ and, after $24 \mathrm{~h}$, treated for further $24 \mathrm{~h}$ with $\mathrm{TiO}_{2} \mathrm{NF}$ at the dose of $10 \mu \mathrm{g} / \mathrm{cm}^{2} .20 \mathrm{~min}$ before the end of exposure, medium was supplemented with CellTracker ${ }^{\mathrm{TM}}$ Red CMPTX ( $8 \mu \mathrm{M}$, Molecular Probes, Invitrogen, Carlsbad, CA, USA) to label the cytoplasm and; in the last 5 min, with 1,5-bis[2-(di-methylamino)ethyl]amino-4, 8dihydroxyanthracene-9,10-dione (DRAQ5 ${ }^{\circledR}, 20 \mu \mathrm{M}$, Alexis Biochemicals, San Diego, CA, USA) to counterstain the nuclei. Cells were then fixed with $3.7 \%$ paraformaldehyde (15 min RT) and observed. Reflectance at $488 \mathrm{~nm}$ or excitation at $543 \mathrm{~nm}$ and emission recorded through a $580-630 \mathrm{~nm}$ band pass barrier filter were used to visualize $\mathrm{TiO}_{2} \mathrm{NF}$ and the cytoplasm, respectively.

For the analysis of epithelial monolayers, 16HBE monolayers, grown on membrane filters, were washed with PBS and incubated for $5 \mathrm{~min}$ in absolute methanol at $-4^{\circ} \mathrm{C}$. Fixed cells were then treated for $10 \mathrm{~min}$ with $10 \%$ of Triton-X100 in PBS, incubated for further $2 \mathrm{~h}$ in a solution of $10 \% \mathrm{BSA}$ and $2 \%$ of Normal Goat Serum (DAKO SpA, Milan, Italy), then incubated overnight in the presence of primary antibodies (antiClaudin-7, rabbit polyclonal; anti ZO-1, mouse polyclonal, both at 1:400, R\&D

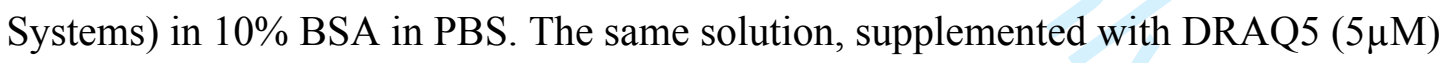
for nuclei counterstaining, was exploited for the incubation with secondary antibodies Alexa Fluor 488 goat anti-mouse and Alexa Fluor 543 goat anti-rabbit for the detection of ZO-1 and claudin-7, respectively. At the end of the incubation, filters were mounted on glass slides. Confocal images were taken with excitation at $543 \mathrm{~nm}$ and emission recorded through a 580- to 630-nm band pass barrier filter for Alexa Fluor 543 to visualize claudin-7 and excitation at $488 \mathrm{~nm}$ and emission through a 515- to 540-nm band pass filter for Alexa Fluor 488 to visualize ZO-1. 
Both analyses were performed with a LSM 510 Meta scan head integrated with an inverted microscope (Carl Zeiss, Jena, Germany) using a 63x (1.4 NA) oil objective. In both cases, excitation at $633 \mathrm{~nm}$ and emission recorded through a 670 long pass filter were adopted for nuclei visualization with DRAQ5.

\subsection{Scanning Electron Microscopy (SEM)}

Macrophages were seeded on coverslips in 24-well plates (ThermanoxTM, Scientific Laboratory Supplies Limited, Hessle, UK). After 24h cells, were treated with cell culture medium with L- or S- $\mathrm{TiO}_{2} \mathrm{NF}$ (both at $10 \mu \mathrm{g} / \mathrm{cm}^{2}$ ) or in plain medium for $24 \mathrm{~h}$. Cells were then rinsed in $\mathrm{NaCl} 0.9 \%$ and fixed overnight at $4{ }^{\circ} \mathrm{C}$ in glutaraldehyde $(3 \%$ in $0.1 \mathrm{M}$ sodium cacodylate buffer). The preparations were gradually dehydrated with subsequent incubation with increasing concentrations of ethanol. Coverslips were then treated for 10 min with hexamethyldisilazane and, after drying, mounted on SEM stub, sputter coated with gold and analysed using a Scanning Electron Microscope (SEM, Oxford Instruments).

\subsection{In vivo experiments}

For the in vivo studies, eight-week-old C57BL/6 male mice were obtained from Charles River Italia (Calco, LC, Italy) and housed in the Tor Vergata Animal Technology Station or The University of Edinburgh under standard conditions $\left(25^{\circ} \mathrm{C}, 50 \%\right.$ relative humidity) on a $12 \mathrm{~h}$ light/dark cycle with free access to water and laboratory animal food. All animal procedures were in compliance with the European Legislation (2010/63/EU) and have been approved by the Institutional Animal Care and Use Committee of the University of Tor Vergata or of the University of Edinburgh.

For the pharyngeal aspiration experiments, C57BL/6 mice of 20-22 $\mathrm{g}$ were 
anaesthetized using a mixture of Ketalar ${ }^{\circledR}, 1 \mathrm{mg} / \mathrm{mouse}$ (Warner-Lambert, Zaventem, Belgium), and Rompun ${ }^{\circledR}, 0.2 \mathrm{mg} / \mathrm{mouse}$ (Bayer, Leverkusen, Germany) given intraperitoneally. At least 3 animals were included in each experimental group. The procedure was performed as previously described (Polimeni et al., 2016). Both ${\mathrm{L}-\mathrm{TiO}_{2}-}^{-}$ $\mathrm{NF}$ and $\mathrm{S}-\mathrm{TiO}_{2}-\mathrm{NF}$ were dispersed in distilled water containing $1.4 \mathrm{mg} / \mathrm{ml}$ endotoxinfree BSA and sonicated on ice. Each mouse received $50 \mu \mathrm{l}$ of a suspension containing $40 \mu \mathrm{g}$ of either $\mathrm{L}_{-}-\mathrm{TiO}_{2}-\mathrm{NF}$ or $\mathrm{S}-\mathrm{TiO}_{2}-\mathrm{NF}$. At the end of the procedure, animals were allowed to recover on a heated pad and then located back in their cages. Control animals were treated with an equivalent volume of sterile water containing $1.4 \mathrm{mg} / \mathrm{ml} \mathrm{BSA}$. After 14 days, Bronchoalveolar Lavage (BAL) was performed under terminal anaesthesia by cannulating the trachea and lavaging with $1 \mathrm{ml}$ of ice-cold saline solution. The lavage was then centrifuged at $200 \times \mathrm{g}$ for $10 \mathrm{~min}$ at $4{ }^{\circ} \mathrm{C}$ and the supernatant was stored at $-80{ }^{\circ} \mathrm{C}$ for further biochemical analysis

For the intraperitoneal experiments, mice of 20-22 g were injected intraperitoneally at a dose of $100 \mu \mathrm{g} / \mathrm{ml}(0.5 \mathrm{ml}$; total dose $50 \mu \mathrm{g}$ per mouse $)$ with each particle suspended in sterile $0.5 \% \mathrm{BSA} /$ saline solution or vehicle control. After 24-hrs, the mice were sacrificed by cervical dislocation and the peritoneal cavity lavaged using $3 \times 2 \mathrm{ml}$ washes of ice-cold sterile saline which were pooled together on ice. The lavage fluid was centrifuged to isolate the cellular fraction and separate the cellular fraction. Cyto-centrifugation preparations were made using the isolated cells and differential cell counts were performed to determine leukocyte populations.

\subsection{Cytokine secretion}

TNF $\alpha$ and IL6 secretion in the culture media of Raw264.7 cells was determined with the ELISA RayBio ${ }^{\circledR}$ kit (Ray Biotech, Norcross, GA, USA) as described in Bianchi et 
al.(Bianchi et al., 2015).The determination of IL-6, TNF $\alpha$ and TGF $\beta$ secretion in BAL samples, derived from mice exposed to $\mathrm{L}-\mathrm{TiO}_{2} \mathrm{NF}$ or $\mathrm{S}-\mathrm{TiO}_{2} \mathrm{NF}$, was performed using the ELISA kit from EIAab ${ }^{\circledR}$ Science (Optics Valley, Wuhan, China) following the manufacturer's instructions.

\subsection{Statistical analysis}

For viability, trans-epithelial electrical resistance and permeability data were analyzed with ANOVA with Bonferroni post hoc test. Data of nitrite concentration, gene expression and cytokine secretion were analyzed with two-tail $t$ test for unpaired data. A p value $<0.05$ was considered statistically significant. GraphPad Prism5 $5^{\mathrm{TM}}$ software was used for statistical analyses.

\subsection{Chemicals}

Sigma-Aldrich was the source of the all the chemicals whenever not stated otherwise.

\section{Results}

\subsection{Physico-chemical characterization of long and ball milled $\mathrm{TiO}_{2} \mathrm{NF}$}

$\mathrm{TiO}_{2}$ nanofibers (NF), produced by an electro-spinning process (see Materials and Methods), were modified with a "size control" strategy through a ball milling treatment, which was chosen due to its industrial relevance as well as low cost and easily scalable characteristics. This strategy was applied in order to decrease length and aspect ratio (AR) of the fibers and, thus, as a remediation step in the manufacturing line.

The starting pristine NF were found to be very inhomogeneous but showed the desired nanostructured morphology, as demonstrated by high specific surface area by 
BET measurements. As expected, the milling treatment did not affect fiber diameter, although it produced a modification of the average fiber length with a consequent, significant decrease of aspect ratio (Table 2).

\subsection{Effects of $\mathrm{TiO}_{2} \mathrm{NF}$ on cell viability}

Figure 1 reports data of cell viability obtained in A549 and 16HBE cells treated with 20, 40 and $80 \mu \mathrm{g} / \mathrm{cm}^{2}$ of either L- or S-TiO 2 NF for 24, 48 or $72 \mathrm{~h}$. In A549 cells (Figure 1, A-B-C), $\mathrm{L}-\mathrm{TiO}_{2} \mathrm{NF}$ caused a clear-cut dose- and time-dependent decrease of cell viability, with a maximal effect of $60 \%$ at $80 \mu \mathrm{g} / \mathrm{cm}^{2}$ obtained after $72 \mathrm{~h}$ of treatment. Fiber shortening almost completely abolished the toxicity of the fibers with marginally significant viability loss that, however, was not dose- or time-dependent.

16HBE cells (Figure 1, D-E-F) were much less sensitive than A549 cells to the toxicity of $\mathrm{L}_{-} \mathrm{TiO}_{2} \mathrm{NF}$, with the maximal effect (30\% reduction in viability) recorded at $72 \mathrm{~h}$ of exposure. However, the toxicity of $\mathrm{L}-$ and $\mathrm{S}-\mathrm{TiO}_{2} \mathrm{NF}$ was low and comparable except for the 72h-time point, when L-NF were more toxic than S-NF at the higher doses. Interestingly, the toxicity of S-NF was larger, although mild, for 16HBE cells than for A549 cells. In both cell models, the benchmark material NM-401 MWCNT caused a marked time-dependent decrease of cell viability, which was more evident in A549 than in $16 \mathrm{HBE}$ cells.

\subsection{Impact of $\mathrm{TiO}_{2} \mathrm{NF}$ on airway epithelial barrier integrity}

Figure 2 (Panel A) reports the time course of changes in Trans-Epithelial Electrical Resistance (TEER) of $16 \mathrm{HBE}$ cell monolayers exposed to $\mathrm{TiO}_{2} \mathrm{NF}\left(80 \mu \mathrm{g} / \mathrm{cm}^{2}\right)$ up to 19d. $\mathrm{L}-\mathrm{TiO}_{2} \mathrm{NF}$ significantly lowered TEER by $30 \%$ after $4 \mathrm{~d}$ of exposure. At longer times, TEER exhibited a partial recovery but remained significantly lower than control 
monolayers. With $\mathrm{S}-\mathrm{TiO}_{2} \mathrm{NF}, \mathrm{TEER}$ decrease was smaller throughout the experiment and, at 19d of treatment, was no more different from control (Panel B). As expected, the benchmark MWCNT preparation produced a large TEER decrease with no sign of recovery. TEER changes were associated to significant increases in fluorescein permeability in monolayers treated with $\mathrm{F}-\mathrm{TiO}_{2} \mathrm{NF}$ and MWCNT (Panel C), while no significant loss of viability was detected in any condition (Panel D).

Changes in trans-epithelial permeability and resistance are associated with alterations in the distribution of tight junction proteins (Figure 3). The confocal images show that, compared with control conditions (Panel A), a 19d-exposure to $\mathrm{L}_{-} \mathrm{TiO}_{2} \mathrm{NF}$ (Panel B) caused a marked and widespread perturbation of the distribution of Claudin-7 and ZO-1, while only milder changes are detected in monolayers treated with $\mathrm{S}-\mathrm{TiO}_{2}$ NF (C). In particular, the orthogonal projections indicated that Claudin-7 was delocalized to the cytoplasm in a high fraction of cells in panel B, while were maintained in close proximity of ZO-1 in most cells of panel C.

\subsection{Nanofiber internalization by macrophages}

To investigate macrophage behavior after challenge with $\mathrm{TiO}_{2} \mathrm{NF}$ we used both confocal microscopy (Figure 4, A-C) and SEM (Figure 4, D-F). Confocal microscopy showed that bundles of nanofibers were readily detected in macrophage cultures exposed either to $\mathrm{L}_{-} \mathrm{TiO}_{2} \mathrm{NF}$ (Panel B) or to $\mathrm{S}-\mathrm{TiO}_{2} \mathrm{NF}$ (Panel C). Only limited internalization of $\mathrm{L}-\mathrm{TiO}_{2} \mathrm{NF}$ occurred, while many short nanofibers were detected inside the cells. However, in both cases, no co-localization of internalized NF with the cytoplasmic marker was observed, indicating that the material was sequestered in a compartment other than cytoplasm. In cultures treated with $\mathrm{L}_{-} \mathrm{TiO}_{2}$ fibers, several cells tended to adhere to the same bundle, while macrophages exposed to $\mathrm{S}-\mathrm{TiO}_{2} \mathrm{NF}$ 
appeared elongated. SEM images revealed morphological deformations in macrophages exposed to $\mathrm{L}^{-\mathrm{TiO}_{2}} \mathrm{NF}$ (Panel E), while in cultures exposed to $\mathrm{S}-\mathrm{TiO}_{2} \mathrm{NF}$ (Panel F) cells were larger and more elongated than control (Panel D) although no gross alteration was detected.

\subsection{Inflammatory response of murine macrophages exposed to long and short $\mathrm{TiO}_{2} \mathrm{NF}$}

Figure $5 \mathrm{~A}$ reports nitrite concentration in the medium, as a proxy of nitric oxide (NO) production, of Raw 264.7. macrophages exposed to increasing doses of $\mathrm{TiO}_{2} \mathrm{NF}$ (range $20-80 \mu \mathrm{g} / \mathrm{cm}^{2}$ ). In cells treated with $\mathrm{L}_{-} \mathrm{TiO}_{2} \mathrm{NF}$, NO production was only slightly increased at 40 and $80 \mu \mathrm{g} / \mathrm{cm}^{2}$. Much larger NO production was detected in the Raw264.7 cells incubated with $\mathrm{S}-\mathrm{TiO}_{2} \mathrm{NF}$, with significant $\mathrm{NO}$ output already present at the lowest dose tested $\left(20 \mu \mathrm{g} / \mathrm{cm}^{2}\right)$. These data were consistent with the level of Nos 2 expression (Figure 5B), which was more than 30 -fold stimulated in cells treated for $24 \mathrm{~h}$ with $\mathrm{S}-\mathrm{TiO}_{2} \mathrm{NF}$ but only 3 -fold induced by $\mathrm{L}_{-}-\mathrm{TiO}_{2} \mathrm{NF}$ at the same dose $\left(80 \mu \mathrm{g} / \mathrm{cm}^{2}\right)$. A larger pro-inflammatory activity of S- compared to $\mathrm{L}-\mathrm{TiO}_{2} \mathrm{NF}$ was also observed when the expression of Ptgs2, the gene which encodes for Cox2, was investigated (Figure 5C). At the same experimental time, also the expression of $I l l b$ was significantly induced, with a larger effect of S- compared with $\mathrm{L}-\mathrm{TiO}_{2} \mathrm{NF}$ (Panel 5D). After a 48h treatment, both TNF- $\alpha$ and IL-6 secretion was markedly stimulated by S-TiO 2 NF in a dose-dependent manner, while $\mathrm{L}_{-} \mathrm{TiO}_{2} \mathrm{NF}$ were ineffective.

To investigate the mechanism underlying the higher pro-inflammatory activity of $\mathrm{S}-\mathrm{TiO}_{2} \mathrm{NF}$, Raw264.7 cells were exposed for $48 \mathrm{~h}$ to the materials $\left(40 \mu \mathrm{g} / \mathrm{cm}^{2}\right)$ in the presence or in the absence of the cytoskeletal drug cytochalasin B $(5 \mu \mathrm{g} / \mathrm{ml})$, which prevents actin polymerization and, hence, phagocytosis (Figure 6). Under these conditions, nitrite production was almost completely suppressed. On the contrary, 
cytochalasin $\mathrm{B}$ did not reduce nitrite production in cells exposed to $\mathrm{L}_{-} \mathrm{TiO}_{2} \mathrm{NF}$ and only marginally decreased it in LPS-treated cultures.

\subsection{Airway cytokine secretion after the exposure to $L$ or $S$ nanofibers}

To evaluate in vivo effects of $\mathrm{TiO}_{2} \mathrm{NF}, \mathrm{C} 57 \mathrm{BL} / 6$ mice were exposed to $\mathrm{L}-$ or $\mathrm{S}-\mathrm{TiO}_{2} \mathrm{NF}$ (40 $\mu \mathrm{g}$ /animal) through pharyngeal aspiration and, after $14 \mathrm{~d}$, the levels of TGF- $\beta$, TNF$\alpha$ and IL- 6 were measured in the bronchoalveolar lavage (BAL) fluid. $\mathrm{L}-\mathrm{TiO}_{2} \mathrm{NF}$ induced significant increase of the three cytokines (Figure 7), while no significant changes were detected in BAL cytokine levels between animals treated with $\mathrm{S}-\mathrm{TiO}_{2} \mathrm{NF}$ and control mice.

\subsection{Peritoneal inflammation after the exposure to $L$ or $S$ nanofibers}

The peritoneal and pleural cavities have very defined routes of clearance with pore-like stomata of $2-8 \mu \mathrm{m}$ in diameter being found in the peritoneal diaphragm and chest wall, respectively. Materials that cannot penetrate these stomata and access the underlying draining lymphatic system can be retained at the mesothelial surface where they may trigger inflammation (Murphy et al., 2011). As shown in Figure 8A, internalized L$\mathrm{TiO}_{2}$ NFs were only occasionally detected (Figure $8 \mathrm{~A}$ ), while $\mathrm{S}-\mathrm{TiO}_{2} \mathrm{NF}$ were seen within several macrophages (Figure 8B). Administration of long but not of short fibers led to a significant elevation in peritoneal granulocytes (Figure $8 \mathrm{C}$ ), which was most notable for the LFA sample (P 0.0004). The influx of neutrophils was significantly higher in animals treated with $\mathrm{L}_{-} \mathrm{TiO}_{2}$ NF compared with control animals (P 0.0136) or animals exposed to $\mathrm{S}-\mathrm{TiO}_{2} \mathrm{NF}(\mathrm{P}$ 0.0166). 


\section{Discussion}

In this study we compare the biological effects of two preparations of $\mathrm{TiO}_{2} \mathrm{NF}$ derived from an industrial process and characterized by different lengths. The longer preparation $\left(\mathrm{L}-\mathrm{TiO}_{2} \mathrm{NF}\right)$ is endowed with features consistent with the dimensional criteria of a respirable fiber (length $>5 \mu \mathrm{m}$, diameter $<3 \mu \mathrm{m}$, length-to-width ratio (aspect ratio) $>3: 1(1997))$. $\mathrm{S}-\mathrm{TiO}_{2} \mathrm{NF}$ have been obtained from $\mathrm{L}_{-} \mathrm{TiO}_{2} \mathrm{NF}$ by milling with $\mathrm{ZrO}_{2}$ microspheres, thus causing a marked decrease of average fiber length, as well as of their aspect ratio. However, although both the preparations have the aspect ratio of a respirable fiber, only $\mathrm{L}_{-} \mathrm{TiO}_{2} \mathrm{NF}$ have an average length $>5 \mu \mathrm{m}$.

A previous in vitro study (Allegri et al., 2016a) has demonstrated that $\mathrm{L}^{-\mathrm{TiO}_{2}}$ $\mathrm{NF}$ are more cytotoxic than $\mathrm{TiO}_{2}$ nanoparticles and cause a sizable decrease of the trans-epithelial electrical resistance of airway cell monolayers. On the contrary, the expression of several pro-inflammatory markers was not substantially different in macrophages exposed to $\mathrm{L}-\mathrm{TiO}_{2} \mathrm{NF}$ or to $\mathrm{TiO}_{2}$ nanoparticles.

Here the biological effects $\mathrm{L}-\mathrm{TiO}_{2} \mathrm{NF}$ have been compared with those caused by shortened fibers. In two human airway cell lines, which exhibited different sensitivities to the toxic effects of $\mathrm{L}_{-}-\mathrm{TiO}_{2} \mathrm{NF}$ (alveolar A549 cells > bronchial 16HBE cells), viability studies indicated that $\mathrm{L}-\mathrm{TiO}_{2} \mathrm{NF}$ are more cytotoxic than $\mathrm{S}-\mathrm{TiO}_{2} \mathrm{NF}$. Lengthdependent toxicity of $\mathrm{TiO}_{2} \mathrm{HARNs}$ was also described in rat alveolar macrophages by Hamilton et al. (Hamilton et al., 2009), who found that only the longer nanobelts were significantly cytotoxic at relatively high doses. These authors proposed that the mechanism of long-fiber toxicity was attributable to post-phagocytosis lysosomal destabilisation, resulting in the release of destructive enzymes, such as cathepsin B, into the cytoplasm (Hamilton et al., 2009). Here we demonstrate that length-dependent 
toxicity of $\mathrm{TiO}_{2}$ HARNs is not specific for specialized phagocytic cells but extends to epithelial airway cells which represent primary targets upon respiratory exposure.

Functional consequences of the exposure of epithelial cells to $\mathrm{TiO}_{2} \mathrm{NF}$ have been also investigated. Indeed, loss of epithelial barrier competence and monolayer integrity are important parameters correlated to penetration of the nanomaterials into the bronchial wall, alterations of epithelial functions and nanomaterial bio-persistence (Rotoli et al., 2008, Banga et al., 2012). L-TiO 2 NF, but not $\mathrm{S}-\mathrm{TiO}_{2} \mathrm{NF}$, cause a clearcut epithelial barrier impairment, indicated by the decrease in TEER, the increase in fluorescein permeability and an evident alteration in the distribution of the tightjunction proteins claudin-7 and ZO-1 in correspondence to NF agglomerates. Similar effects on TEER were observed upon exposure of airway epithelial cells to long, needle-like MWCNT (Farcal et al., 2015, Rotoli et al., 2015), which are used here as benchmark materials. In the case of MWCNT, loss of barrier integrity is due to a focal damage to the epithelial cell monolayer, attributable to the interaction with nanomaterial agglomerates, in the absence of a generalized decrease in monolayer viability (Rotoli et al., 2015). The confocal images reported here, along with lack of viability loss at the whole population level, suggest that a similar mechanism underlies $\mathrm{L}_{-} \mathrm{TiO}_{2} \mathrm{NF}$ effects. Interestingly, as observed here for $\mathrm{TiO}_{2} \mathrm{NF}$, length is an important structural determinant for epithelial barrier damage also for MWCNT (Rotoli et al., 2009).

In their toxicological assessment of short $(0.8-4 \mu \mathrm{m})$ and long $(15-30 \mu \mathrm{m})$ $\mathrm{TiO}_{2}$ nanobelts (Hamilton et al., 2009), Hamilton et al. noted that only long $\mathrm{TiO}_{2}$ nanobelts led to a significant increase in IL-1 $\beta$ release (a proxy measure for the NALP3 inflammasome formation) by LPS-primed rat alveolar macrophages, suggesting that length also influences inflammation. Using $\mathrm{TiO}_{2}$ nanobelts of intermediate length (7 $\mu \mathrm{m})$, Tilton et al. performed a transcriptomic and proteomic analysis of treated human 
macrophages, demonstrating changes in the expression of inflammatory genes (Tilton et al., 2014). Those results were further extended in vivo (Porter et al., 2013), demonstrating that mice, exposed through pharyngeal aspiration to $\mathrm{TiO}_{2}$ nanobelts, developed significant dose- and time-dependent pulmonary inflammation and fibrosis, with much more evident alterations in animals treated with longer nanostructures (Porter et al., 2013). The results shown here after aspiration of $\mathrm{L}-$ and $\mathrm{S}_{-} \mathrm{TiO}_{2}$ nanofibers are consistent with those data, since only longer preparation caused a persistent cytokine secretion. Interestingly, among the cytokines tested, besides the typical proinflammatory IL-6 and TNF- $\alpha$, a significant increase is also detected for the fibrogenic cytokine TGF- $\beta$, suggesting a pro-fibrotic activity of $\mathrm{L}-\mathrm{TiO}_{2} \mathrm{NF}$ in vivo. Furthermore, in vivo administration through intra-peritoneal injection has demonstrated that retention at the mesothelial surface of long but not short NF leads to a prominent inflammatory response as indicated by a larger granulocyte influx.

In contrast with data obtained in vivo, the results presented here indicate however, that shortened NF have a more evident pro-inflammatory activity than long $\mathrm{NF}$, as evaluated from early activation events in murine macrophages in vitro. This effect cannot be attributed to LPS contamination during the ball milling procedure. LPS contamination of nanomaterials constitutes a frequently encountered, and often overlooked, problem in nanotoxicology (Esch et al., 2010, Smulders et al., 2012). Moreover, recent work from our laboratory has demonstrated that adsorption to nanomaterials may synergize the pro-inflammatory effects of LPS (Bianchi et al., 2015, Di Cristo et al., 2016, Bianchi et al., 2017). However, the NF used in this contribution have been thermally pre-treated just before cell exposure and, therefore, are to be considered LPS-free. Thus, the effects observed on the induction of pro-inflammatory genes, inflammatory mediators and cytokine secretion should be attributed to intrinsic 
properties of NF rather than to a combined effect of NF and LPS, as in the experiments reported by Hamilton et al. (Hamilton et al., 2009). It may be the case that in the complex and self-regulating environment of the lung, such pro-inflammatory stimuli serve to increase the rate of clearance of particulates through a controlled response. Such a response noted in vitro may not be elevated in vivo (at the doses used for more easily cleared low aspect ratio particulates) up to a full inflammatory response and, therefore, would be an adaptive ('dust') response rather than a true inflammation. The experiments reported here provide some information on the mechanism involved in the higher pro-inflammatory potential of $\mathrm{S}^{-\mathrm{TiO}_{2}} \mathrm{NF}$ in vitro. Indeed, the inhibition of phagocytosis by the cytoskeletal drug cytochalasin B severely hampers NO production by $\mathrm{S}-\mathrm{TiO}_{2} \mathrm{NF}$ but not by $\mathrm{L}-\mathrm{TiO}_{2} \mathrm{NF}$. On the other hand, $\mathrm{S}-\mathrm{TiO}_{2} \mathrm{NF}$ are much more efficiently internalized than longer counterparts (see Figures 4 and 8), which would lead to a high intracellular dose. These arguments support the hypothesis that phagocytosis of NF is involved in the brisk, but possibly transient, macrophage activation observed upon the exposure to $\mathrm{S}-\mathrm{TiO}_{2} \mathrm{NF}$, a characteristic of self-limited 'dust' response. Interestingly, all the inflammatory parameters tested (NO production, induction of inflammatory genes, TNF- $\alpha /$ IL- 6 secretion) are related to the M1 activation type (Mills et al., 2000, Murray et al., 2014).

Confocal microscopy and SEM showed that most cells incubated with $\mathrm{S}_{-} \mathrm{TiO}_{2}$ internalized the material, displaying a nearby-normal rounded morphology or a symmetrically elongated morphology, indicative of cell activation, but no severe distortion or stretching. On the contrary, the incubation with long fibers caused marked cell stretching along the fiber surface, with several cells aligned along or penetrated by the same fiber but with very few cells exhibiting clear cut internalization. This situation of attempted, partial or failed internalization is indicative of frustrated phagocytosis, as 
reported for other fibrous nanomaterials (Hamilton et al., 2009, Sweeney et al., 2015). As suggested by Schinwald et al. (Schinwald et al., 2012b), this situation can cause hindered macrophage motility, occurs at fiber lengths greater than $5 \mu \mathrm{m}$ and, hence, would be relevant to the $\mathrm{L}$ - but not to the $\mathrm{S} \mathrm{TiO}_{2} \mathrm{NF}$. Within the in vivo context, impaired macrophage-mediated clearance of NF from the lung could lead to increased lung burden over time. On the contrary, exposure to $\mathrm{S}-\mathrm{TiO}_{2} \mathrm{NF}$ is expected to trigger efficient phagocytosis with enhanced clearance of the nanomaterial and, consistently, such efficient uptake was noted in the peritoneal model.

Data obtained after in vivo respiratory exposure are also consistent with this hypothesis, since the more prolonged inflammatory reaction observed with $\mathrm{L}_{-} \mathrm{TiO}_{2} \mathrm{NF}$, documented by the higher cytokine levels in BAL (Figure 7), could be associated with a higher biopersistence of this preparation. In accordance, Porter et al. reported that, after more than $100 \mathrm{~d}$ from exposure, a sizable proportion of long $\mathrm{TiO}_{2}$ nanobelts was still present in the lung (Porter et al., 2013). This substantial retention may be the result of both impaired macrophage-mediated clearance and increased permeation of the altered epithelial barrier. Importantly, the results presented here indicate that L-, but not $\mathrm{S}-\mathrm{TiO}_{2}$ NF, are able to produce a sustained secretion of pro-inflammatory and fibrogenic cytokines in the lung as well as a marked leukocyte influx in the peritoneal model. Thus, the increased bio-persistence of long NF is expected to trigger more chronic responses (Figure 9).

\section{Acknowledgements}

The confocal images were obtained in the Laboratory of Confocal Microscopy of the Department of Medicine and Surgery of the University of Parma. 


\section{Disclosure statement}

The authors declare that there are no conflicts of interest.

\section{Funding}

This work was supported by the EU FP7 SANOWORK Project (Grant agreement $\mathrm{n}$.

280716, http://sanowork.eu/) to EB and ALC and by EU Horizon 2020 BIORIMA

Project (Grant agreement n. 760928) to EB. CAP is funded by the Colt Foundation and

RD by the MRC \& Colt Foundation. MC is supported by a fellowship of "Associazione Italiana per la Ricerca sul Cancro" (AIRC, no. 19272).

\section{References}

Allegri, M., Bianchi, M.G., Chiu, M., Varet, J., Costa, A.L., Ortelli, S., Blosi, M., Bussolati, O., Poland, C.A. \& Bergamaschi, E., 2016a. Shape-Related Toxicity of Titanium Dioxide Nanofibres. PLoS One, 11, e0151365.

Allegri, M., Perivoliotis, D.K., Bianchi, M.G., Chiu, M., Pagliaro, A., Koklioti, M.A., Trompeta, A.A., Bergamaschi, E., Bussolati, O. \& Charitidis, C.A., 2016 b. Toxicity determinants of multi-walled carbon nanotubes: The relationship between functionalization and agglomeration. Toxicol Rep, 3, 230-243.

Banga, A., Witzmann, F.A., Petrache, H.I. \& Blazer-Yost, B.L., 2012. Functional effects of nanoparticle exposure on Calu-3 airway epithelial cells. Cell Physiol Biochem, 29, 197-212.

Bartel, L.K., Hunter, D.A., Anderson, K.B., Yau, W., Wu, J. \& Gato, W.E., 2018. Short-term evaluation of hepatic toxicity of titanium dioxide nanofiber (TDNF). Drug Chem Toxicol, 1-8.

Bianchi, M.G., Allegri, M., Chiu, M., Costa, A.L., Blosi, M., Ortelli, S., Bussolati, O. \& Bergamaschi, E., 2017. Lipopolysaccharide Adsorbed to the Bio-Corona of TiO2 Nanoparticles Powerfully Activates Selected Pro-inflammatory Transduction Pathways. Front Immunol, 8, 866.

Bianchi, M.G., Allegri, M., Costa, A.L., Blosi, M., Gardini, D., Del Pivo, C., PrinaMello, A., Di Cristo, L., Bussolati, O. \& Bergamaschi, E., 2015. Titanium dioxide nanoparticles enhance macrophage activation by LPS through a TLR4dependent intracellular pathway. Toxicology Research, 4, 385-398.

Bustin, S.A., 2000. Absolute quantification of mRNA using real-time reverse transcription polymerase chain reaction assays. J Mol Endocrinol, 25, 169-93.

Davis, J., Addison, J., Bolton, R., Donaldson, K., Jones, A. \& Smith, T., 1986a. The pathogenicity of long versus short fibre samples of amosite asbestos administered to rats by inhalation and intraperitoneal injection. Br J Exp Pathol, $67,415-430$.

Davis, J.M., Addison, J., Bolton, R.E., Donaldson, K., Jones, A.D. \& Smith, T., 1986b. The pathogenicity of long versus short fibre samples of amosite asbestos 
administered to rats by inhalation and intraperitoneal injection. Br J Exp Pathol, $67,415-430$.

Davis, J.M., Addison, J., Mcintosh, C., Miller, B.G. \& Niven, K., 1991. Variations in the carcinogenicity of tremolite dust samples of differing morphology. Ann NY Acad Sci, 643, 473-90.

Davis, J.M. \& Jones, A.D., 1988. Comparisons of the pathogenicity of long and short fibres of chrysotile asbestos in rats. Br J Exp Pathol, 69, 717-37.

Di Cristo, L., Movia, D., Bianchi, M.G., Allegri, M., Mohamed, B.M., Bell, A.P., Moore, C., Pinelli, S., Rasmussen, K., Riego-Sintes, J., Prina-Mello, A., Bussolati, O. \& Bergamaschi, E., 2016. Proinflammatory Effects of Pyrogenic and Precipitated Amorphous Silica Nanoparticles in Innate Immunity Cells. Toxicol Sci, 150, 40-53.

Donaldson, K., Brown, G.M., Brown, D.M., Bolton, R.E. \& Davis, J.M., 1989. Inflammation generating potential of long and short fibre amosite asbestos samples. Br J Ind Med, 46, 271-6.

Donaldson, K., Murphy, F., Schinwald, A., Duffin, R. \& Poland, C.A., 2011. Identifying the pulmonary hazard of high aspect ratio nanoparticles to enable their safety-by-design. Nanomedicine, 6, 143-156.

Donaldson, K. \& Poland, C.A., 2013. Nanotoxicity: challenging the myth of nanospecific toxicity. Current Opinion in Biotechnology, 24, 724-734.

Donaldson, K., Schinwald, A., Murphy, F., Cho, W.S., Duffin, R., Tran, L. \& Poland, C., 2013. The biologically effective dose in inhalation nanotoxicology. Acc Chem Res, 46, 723-32.

Donaldson, K. \& Tran, C.L., 2004. An introduction to the short-term toxicology of respirable industrial fibres. Mutation research, 553, 5-9.

Esch, R.K., Han, L., Foarde, K.K. \& Ensor, D.S., 2010. Endotoxin contamination of engineered nanomaterials. Nanotoxicology, 4, 73-83.

Farcal, L., Torres Andon, F., Di Cristo, L., Rotoli, B.M., Bussolati, O., Bergamaschi, E., Mech, A., Hartmann, N.B., Rasmussen, K., Riego-Sintes, J., Ponti, J., KinsnerOvaskainen, A., Rossi, F., Oomen, A., Bos, P., Chen, R., Bai, R., Chen, C., Rocks, L., Fulton, N., Ross, B., Hutchison, G., Tran, L., Mues, S., Ossig, R., Schnekenburger, J., Campagnolo, L., Vecchione, L., Pietroiusti, A. \& Fadeel, B., 2015. Comprehensive In Vitro Toxicity Testing of a Panel of Representative Oxide Nanomaterials: First Steps towards an Intelligent Testing Strategy. PLoS One, 10, e0127174.

Gato, W.E., Hunter, D.A., Byrd, I.C., Mays, C.A., Yau, W. \& Wu, J., 2017. Assessment of the short-term toxicity of $\mathrm{TiO} 2$ nanofiber in Sprague Dawley rats. Environ Toxicol, 32, 1775-1783.

Goodglick, L.A. \& Kane, A.B., 1990. Cytotoxicity of long and short crocidolite asbestos fibers in vitro and in vivo. Cancer Res., 50, 5153-5163.

Hamilton, R.F., Wu, N., Porter, D., Buford, M., Wolfarth, M. \& Holian, A., 2009. Particle length-dependent titanium dioxide nanomaterials toxicity and bioactivity. Part Fibre Toxicol., 6, 35.

Hamilton, R.F., Wu, N.Q., Xiang, C.C., Li, M., Yang, F., Wolfarth, M., Porter, D.W. \& Holian, A., 2014. Synthesis, characterization, and bioactivity of carboxylic acidfunctionalized titanium dioxide nanobelts. Part Fibre Toxicol., 11.

Hunter, D.A., Bartel, L.K., Byrd, I., Bogan, B., Yau, W., Wu, J. \& Gato, W.E., 2018. Short-Term Effects of Titanium Dioxide Nanofiber on the Renal Function of Male Sprague Dawley Rats. J Environ Pathol Toxicol Oncol, 37, 127-138. 
Jessop, F., Hamilton, R.F., Jr., Rhoderick, J.F., Fletcher, P. \& Holian, A., 2017.

Phagolysosome acidification is required for silica and engineered nanoparticleinduced lysosome membrane permeabilization and resultant NLRP3 inflammasome activity. Toxicol Appl Pharmacol, 318, 58-68.

Ji, Z., Wang, X., Zhang, H., Lin, S., Meng, H., Sun, B., George, S., Xia, T., Nel, A.E. \& Zink, J.I., 2012. Designed synthesis of $\mathrm{CeO} 2$ nanorods and nanowires for studying toxicological effects of high aspect ratio nanomaterials. ACS Nano, 6, 5366-80.

Kuschner, M. \& Wright, G., 1976. The effects of intratracheal instillation of glass fiber of varying sizes in guinea pigs. Occupational Exposure to Fibrous Glass. 151169.

Mills, C.D., Kincaid, K., Alt, J.M., Heilman, M.J. \& Hill, A.M., 2000. M-1/M-2 macrophages and the Th1/Th2 paradigm. J Immunol, 164, 6166-73.

Murphy, F.A., Poland, C.A., Duffin, R., Al-Jamal, K.T., Ali-Boucetta, H., Nunes, A., Byrne, F., Prina-Mello, A., Volkov, Y., Li, S., Mather, S.J., Bianco, A., Prato, M., Macnee, W., Wallace, W.A., Kostarelos, K. \& Donaldson, K., 2011. Length-dependent retention of carbon nanotubes in the pleural space of mice initiates sustained inflammation and progressive fibrosis on the parietal pleura. The American journal of pathology, 178, 2587-600.

Murray, P.J., Allen, J.E., Biswas, S.K., Fisher, E.A., Gilroy, D.W., Goerdt, S., Gordon, S., Hamilton, J.A., Ivashkiv, L.B., Lawrence, T., Locati, M., Mantovani, A., Martinez, F.O., Mege, J.L., Mosser, D.M., Natoli, G., Saeij, J.P., Schultze, J.L., Shirey, K.A., Sica, A., Suttles, J., Udalova, I., Van Ginderachter, J.A., Vogel, S.N. \& Wynn, T.A., 2014. Macrophage activation and polarization: nomenclature and experimental guidelines. Immunity, 41, 14-20.

O'brien, J., Wilson, I., Orton, T. \& Pognan, F., 2000. Investigation of the Alamar Blue (resazurin) fluorescent dye for the assessment of mammalian cell cytotoxicity. Eur J Biochem, 267, 5421-6.

Poland, C., Byrne, F., Cho, W., Prina-Mello, A., Murphy, F. \& Davies, G., 2011. Length-dependent pathogenic effects of nickel nanowires in the lungs and the peritoneal cavity. Nanotoxicology, 6, 899 - 911.

Poland, C., Duffin, R., Kinloch, I., Maynard, A., Wallace, W. \& Seaton, A., 2008a. Carbon nanotubes introduced into the abdominal cavity of mice show asbestoslike pathogenicity in a pilot study. Nature nanotechnology, 3, 423 - 428.

Poland, C.A., Duffin, R., Kinloch, I., Maynard, A., Wallace, W.A., Seaton, A., Stone, V., Brown, S., Macnee, W. \& Donaldson, K., 2008b. Carbon nanotubes introduced into the abdominal cavity of mice show asbestos-like pathogenicity in a pilot study. Nature nanotechnology, 3, 423-8.

Polimeni, M., Gulino, G.R., Gazzano, E., Kopecka, J., Marucco, A., Fenoglio, I., Cesano, F., Campagnolo, L., Magrini, A., Pietroiusti, A., Ghigo, D. \& Aldieri, E., 2016. Multi-walled carbon nanotubes directly induce epithelial-mesenchymal transition in human bronchial epithelial cells via the TGF-beta-mediated Akt/GSK-3beta/SNAIL-1 signalling pathway. Part Fibre Toxicol, 13, 27.

Porter, D.W., Wu, N., Hubbs, A.F., Mercer, R.R., Funk, K., Meng, F., Li, J., Wolfarth, M.G., Battelli, L., Friend, S., Andrew, M., Hamilton, R., Jr., Sriram, K., Yang, F., Castranova, V. \& Holian, A., 2013. Differential mouse pulmonary dose and time course responses to titanium dioxide nanospheres and nanobelts. Toxicol Sci, 131, 179-93.

Rotoli, B.M., Bussolati, O., Barilli, A., Zanello, P.P., Bianchi, M.G., Magrini, A., Pietroiusti, A., Bergamaschi, A. \& Bergamaschi, E., 2009. Airway barrier 
dysfunction induced by exposure to carbon nanotubes in vitro: which role for fiber length? Hum Exp Toxicol, 28, 361-8.

Rotoli, B.M., Bussolati, O., Bianchi, M.G., Barilli, A., Balasubramanian, C., Bellucci, S. \& Bergamaschi, E., 2008. Non-functionalized multi-walled carbon nanotubes alter the paracellular permeability of human airway epithelial cells. Toxicol Lett, 178, 95-102.

Rotoli, B.M., Gatti, R., Movia, D., Bianchi, M.G., Di Cristo, L., Fenoglio, I., Sonvico, F., Bergamaschi, E., Prina-Mello, A. \& Bussolati, O., 2015. Identifying contactmediated, localized toxic effects of MWCNT aggregates on epithelial monolayers: a single-cell monitoring toxicity assay. Nanotoxicology, 9, 230-41.

Salem, L.B., Bosquillon, C., Dailey, L.A., Delattre, L., Martin, G.P., Evrard, B. \& Forbes, B., 2009. Sparing methylation of beta-cyclodextrin mitigates cytotoxicity and permeability induction in respiratory epithelial cell layers in vitro. J Control Release, 136, 110-6.

Schinwald, A., Chernova, T. \& Donaldson, K., 2012a. Use of silver nanowires to determine thresholds for fibre length-dependent pulmonary inflammation and inhibition of macrophage migration in vitro. Part Fibre Toxicol., 9, 47.

Schinwald, A., Murphy, F.A., Prina-Mello, A., Poland, C.A., Byrne, F., Movia, D., Glass, J.R., Dickerson, J.C., Schultz, D.A., Jeffree, C.E., Macnee, W. \& Donaldson, K., 2012b. The threshold length for fiber-induced acute pleural inflammation: shedding light on the early events in asbestos-induced mesothelioma. Toxicol Sci, 128, 461-70.

Smulders, S., Kaiser, J.P., Zuin, S., Van Landuyt, K.L., Golanski, L., Vanoirbeek, J., Wick, P. \& Hoet, P.H., 2012. Contamination of nanoparticles by endotoxin: evaluation of different test methods. Part Fibre Toxicol., 9, 41.

Stanton, M.F., Laynard, M., Tegeris, A., Miller, E., May, M. \& Kent, E., 1977. Carcinogenicity of fibrous glass: pleural response in the rat in relation to fiber dimension. J Natl Cancer Inst, 58, 587-603.

Sweeney, S., Grandolfo, D., Ruenraroengsak, P. \& Tetley, T.D., 2015. Functional consequences for primary human alveolar macrophages following treatment with long, but not short, multiwalled carbon nanotubes. Int J Nanomedicine, 10, 3115-29.

Tilton, S.C., Karin, N.J., Tolic, A., Xie, Y., Lai, X., Hamilton, R.F., Jr., Waters, K.M., Holian, A., Witzmann, F.A. \& Orr, G., 2014. Three human cell types respond to multi-walled carbon nanotubes and titanium dioxide nanobelts with cell-specific transcriptomic and proteomic expression patterns. Nanotoxicology, 8, 533-48.

Who, 1997. Determination of airborne fibre number concentrations. A recommended method, by phase-contrast optical microscopy membrane filter method Geneva: World Health Organization.

Xia, T., Hamilton, R.F., Bonner, J.C., Crandall, E.D., Elder, A., Fazlollahi, F., Girtsman, T.A., Kim, K., Mitra, S., Ntim, S.A., Orr, G., Tagmount, M., Taylor, A.J., Telesca, D., Tolic, A., Vulpe, C.D., Walker, A.J., Wang, X., Witzmann, F.A., Wu, N., Xie, Y., Zink, J.I., Nel, A. \& Holian, A., 2013. Interlaboratory evaluation of in vitro cytotoxicity and inflammatory responses to engineered nanomaterials: the NIEHS Nano GO Consortium. Environ Health Perspect, 121, 683-90. 


\section{Figure Legends}

Table 1. Primers and temperatures of annealing adopted for RT-PCR experiments

Table 2. Properties of $\mathrm{L}_{-}-\mathrm{TiO}_{2} \mathrm{NF}$ and $\mathrm{S}-\mathrm{TiO}_{2} \mathrm{NF}$

Figure 1. Effect of $\mathrm{TiO}_{2}$ nanofibers on cell viability. A549 (A,C,E) and 16HBE cells (B,D,F) were exposed for up to $72 \mathrm{~h}$ to the indicated doses of long (L-) or short (S-) $\mathrm{TiO}_{2} \mathrm{NF}$ or to the benchmark material NM-401. Cell viability was assessed with the resazurin assay at $24,48,72 \mathrm{~h}$. Data are means \pm S.D of six independent determinations. $* * \mathrm{p}<0.01, * * * \mathrm{p}<0.001$ vs. control (untreated cultures), as assessed with one-way ANOVA; \#\# $\mathrm{p}<0.01$, \#\#\# $\mathrm{p}<0.001$ between L- and $\mathrm{S}-\mathrm{TiO}_{2} \mathrm{NF}$, as assessed with twotail t-test for unpaired data.

Figure 2. Effect of $\mathrm{TiO}_{2}$ nanofibers on the barrier integrity of human bronchial cell monolayers. 16HBE airway epithelial cells were cultured on membrane filters and, once reached confluence, $\mathrm{L}$ - or $\mathrm{S}-\mathrm{TiO}_{2} \mathrm{NF}$ were added to the apical chamber at the dose of 80 $\mu \mathrm{g} / \mathrm{cm}^{2}$. The Trans-Epithelial Electrical Resistance (TEER) was then measured up to 19d of treatment (A). NM-401 MWCNT, used as benchmark material, were added to other monolayers in parallel. At the end of the experiment TEER (B), fluorescein permeability (C) and cell viability (D) were measured in the same monolayers. Data are means \pm S.D of 4 independent determinations. ${ }^{*} \mathrm{p}<0.05, * * \mathrm{p}<0.01, * * * \mathrm{p}<0.001$ ns, not significant vs. control, untreated cultures; $\# \mathrm{p}<0.05$, \#\# $\mathrm{p}<0.01$ vs. monolayers treated with NM-401 MWCNT.

Figure 3. At the end of the experiment shown in Figure 2, cell monolayers, kept adherent to the filters, were fixed and immunostained for claudin-7 (red) and ZO-1 (green). DRAQ5 (blue) was used to stain nuclei. (A), After the staining procedure, 
filters were trimmed from the transwells, laid down and mounted on the coverslip for observation. Control, untreated monolayers; (B) monolayers treated for 19d with L$\mathrm{TiO}_{2} \mathrm{NF}(80 \mu \mathrm{g} / \mathrm{cm} 2)$; (C) monolayers treated for 19d with $\mathrm{S}-\mathrm{TiO}_{2} \mathrm{NF}(80 \mu \mathrm{g} / \mathrm{cm} 2)$. For each condition, a single horizontal confocal section of a representative field is shown, with orthogonal projections. Areas where signals are not detected are due to changes in observation plan in correspondence of filter deformations. Arrows, cells with gross claudin-7 delocalization. The experiment has been performed twice with similar results. $\operatorname{Bar}=20 \mu \mathrm{m}$

Figure 4. Characterization of nanofiber internalization by Raw264.7 macrophages. Macrophage were seeded on coverslips and, after $24 \mathrm{~h}$, exposed for $24 \mathrm{~h}$ to $\mathrm{L}_{-}-\mathrm{TiO}_{2} \mathrm{NF}$ $(\mathrm{B}, \mathrm{E})$ or $\mathrm{S}-\mathrm{TiO}_{2} \mathrm{NF}(\mathrm{C}, \mathrm{F})$, both at a dose of $10 \mu \mathrm{g} / \mathrm{cm}^{2}$, or incubated in control medium (A, D). Cells were then labelled, fixed, mounted and observed in confocal microscopy (A-C, see Methods) Single-plan horizontal sections of representative fields are shown where $\mathrm{TiO}_{2} \mathrm{NF}$ are pseudo-colored in white, the cytoplasm in red and nuclei in blue. For SEM, monolayers were fixed and dehydrated before being mounted (D-F, see Methods). Bars, $20 \mu \mathrm{m}(\mathrm{A}, \mathrm{B})$ or $10 \mu \mathrm{m}(\mathrm{C}, \mathrm{D})$.

Figure 5. Comparative effects of long and short $\mathrm{TiO}_{2} \mathrm{NF}$ on the expression of proinflammatory markers in Raw 264.7 cells. Macrophages were treated with $\mathrm{L}-\mathrm{TiO}_{2} \mathrm{NF}$ or $\mathrm{S}-\mathrm{TiO}_{2} \mathrm{NF}$ at the indicated doses or with $10 \mathrm{ng} / \mathrm{ml}$ of LPS as a positive control and several inflammatory markers were assessed. $(A, B, C)$ After $24 \mathrm{~h}$ of treatment at the indicated doses of NF, medium nitrite concentration (A), Nos2 expression (B) or Ptgs2 expression (C) were assessed. (D) At the same experimental time, the effects of NF (at the dose of $80 \mathrm{mg} / \mathrm{cm}^{2}$ ) on the expression of $I l 1 b$ were assessed. (E,F) After $48 \mathrm{~h}$ of treatment, the levels of TNF- $\alpha$ and IL- 6 were determined in the extracellular medium. 
Data are means \pm S.D of $3(\mathrm{~B}-\mathrm{F})$ or $4(\mathrm{~A})$ independent determinations. ${ }^{*} \mathrm{p}<0.05,{ }^{*} \mathrm{p}$ $<0.01, * * * p<0.001$ vs. control, untreated cultures; $\$ \$ p<0.01, \$ \$ \$ p<0.001$ vs. the same dose of $\mathrm{L}_{-} \mathrm{TiO}_{2} \mathrm{NF}$, as assessed with two-tail $\mathrm{t}$ test for unpaired data.

Figure 6. Role of $\mathrm{TiO}_{2}$ nanofiber internalization in NO production in Raw 264.7 cells. Nitrite concentration was measured in the culture medium of macrophages exposed for 48h to $\mathrm{L}^{-\mathrm{TiO}_{2}} \mathrm{NF}$ or $\mathrm{S}-\mathrm{TiO}_{2} \mathrm{NF}\left(40 \mu \mathrm{g} / \mathrm{cm}_{2}\right)$ or to LPS $(10 \mathrm{ng} / \mathrm{ml})$ with or without cytochalasin B $(5 \mu \mathrm{g} / \mathrm{ml})$. Data are means $\pm \mathrm{SD}$ of 8 independent determinations in two experiments. ${ }^{* * *} \mathrm{p}<0.001$ vs. control, untreated cultures; $\# \mathrm{p}<0.05$, \#\#\# $\mathrm{p}<0.001$ vs. the same condition without cytochalasin B.

Figure 7. BAL cytokines in $\mathrm{C} 57 \mathrm{BL} / 6$ mice exposed to $\mathrm{TiO}_{2} \mathrm{NF}$. C57BL/6 mice were exposed through pharingeal aspiration to $40 \mu \mathrm{g}$ of $\mathrm{L}$ - (red bars) or $\mathrm{S}-\mathrm{TiO}_{2} \mathrm{NF}$ (blue bars) suspended in sterile water containing $1.4 \mathrm{mg} / \mathrm{ml} \mathrm{BSA}$ or in vehicle alone (control, empty bars). After 14d, BAL were collected and TGF- $\beta$, TNF- $\alpha$ and IL-6 were measured with ELISA. ${ }^{*} \mathrm{p}<0.05,{ }^{*} \mathrm{p}<0.01$ vs. control; ns, not significant vs. control; $\# \mathrm{p}<0.05$ vs. $\mathrm{S}-\mathrm{TiO}_{2} \mathrm{NF}$, as assessed with ANOVA.

Figure 8. Peritoneal lavage granulocytes in $\mathrm{C} 57 \mathrm{BL} / 6$ mice exposed to $\mathrm{TiO}_{2} \mathrm{NF}$ or long fibre (LFA) or short fibre (SFA) amosite asbestos. C57BL/6 mice were exposed through intra-peritoneal injection to $\mathrm{L}^{-\mathrm{TiO}_{2}} \mathrm{NF}, \mathrm{S}-\mathrm{TiO}_{2} \mathrm{NF}$, long fibre amosite, short fibre amosite asbestos (50 $\mathrm{mg}$ of each material) suspended in sterile water containing $0.5 \%$ BSA or to vehicle alone. After $24 \mathrm{~h}$, the peritoneal cavity was lavaged and cells determined via a differential cell count. (A) $\mathrm{L}^{-\mathrm{TiO}_{2}}$ (chevron) containing macrophage. (B). Several macrophages containing $\mathrm{S}-\mathrm{TiO}_{2}$ (chevrons). (C) Percentage granulocytes in 
the peritoneal fluid $* \mathrm{p}<0.05, * * * \mathrm{p}<0.001$ vs. control; $\$ \mathrm{p}<0.05$ vs. $\mathrm{S}-\mathrm{TiO}_{2} \mathrm{NF}$, as assessed with ANOVA $(\mathrm{n}=3)$.

Figure 9. Differential outcomes of exposure to long and shortened $\mathrm{TiO}_{2}$ nanofibers. 


\begin{tabular}{|c|c|c|c|c|c|}
\hline Gene & Protein & Forward & Reverse & $\begin{array}{c}\mathbf{T} \\
\left({ }^{\circ} \mathrm{C}\right)\end{array}$ & $\begin{array}{l}\text { Amplicon } \\
\text { Size (bp) }\end{array}$ \\
\hline Nos 2 & $\begin{array}{l}\text { Inducible Nitric } \\
\text { oxide } \\
\text { synthase (Nos } 2)\end{array}$ & $\begin{array}{l}\text { 5'-GTT CTCAGC CCA ACAATA } \\
\text { CAA GA-3' }\end{array}$ & $\begin{array}{l}\text { 5'-GTG GACGGG TCGATG } \\
\text { TCA C-3' }\end{array}$ & 57 & 127 \\
\hline Ptgs 2 & $\begin{array}{l}\text { Cyclooxygenase- } \\
2 \\
(\mathrm{Cox} 2)\end{array}$ & $\begin{array}{l}5^{\prime}- \\
\text { GCTCAGCCAGGCAGCAAATC- } \\
3^{\prime}\end{array}$ & $\begin{array}{l}\text { '- } \\
\text { ATCCAGTCCGGGTACAGTCA } \\
-3,\end{array}$ & 56 & 107 \\
\hline Gapdh & $\begin{array}{l}\text { Glyceraldehyde } \\
\text { 3- } \\
\text { phosphate } \\
\text { dehydrogenase }\end{array}$ & $\begin{array}{l}\text { 5'-TGT TCCTAC CCC CAATGT } \\
\text { GT-3' }\end{array}$ & $\begin{array}{l}\text { 5'-GGT CCTCAG TGTAGC CCA } \\
\text { AG-3' }\end{array}$ & 57 & 137 \\
\hline$I l 1 b$ & IL-1 $\beta$ & $\begin{array}{l}\text { 5'-GCA ACTGTT CCT GAACTC } \\
\text { AAC T-3' }\end{array}$ & $\begin{array}{l}\text { 5'-ATC TTTTGG GGTCCG } \\
\text { TCAACT-3' }\end{array}$ & 58 & 76 \\
\hline
\end{tabular}

Table 1. Primers and temperatures of annealing adopted for RT-PCR experiments 


\begin{tabular}{|c|c|c|c|c|c|}
\hline & $\begin{array}{c}\text { Average } \\
\text { Length }(\mu \mathrm{m})\end{array}$ & $\begin{array}{c}\text { Average } \\
\text { Diameter } \\
(\mu \mathrm{m})\end{array}$ & $\begin{array}{c}\text { Average } \\
\text { Aspect Ratio }\end{array}$ & $\mathrm{SSA}\left(\mathrm{m}^{2} / \mathrm{g}\right)$ & $\begin{array}{c}\text { Zeta } \\
\text { potential } \\
(\mathrm{mV})\end{array}$ \\
\hline $\mathrm{L}^{-\mathrm{TiO}_{2}} \mathrm{NF}$ & $9.9 \pm 5.8$ & $0.3 \pm 0.1$ & 29:1 & 144.5 & $-35.0 \pm 1.1$ \\
\hline $\mathrm{S}^{-\mathrm{TiO}_{2}} \mathbf{N F}$ & $2.1 \pm 2.4$ & $0.4 \pm 0.1$ & $5.7: 1$ & 138.8 & $-22.5 \pm 1.4$ \\
\hline
\end{tabular}

Table 2. Properties of $\mathrm{L}_{-} \mathrm{TiO}_{2} \mathrm{NF}$ and $\mathrm{S}-\mathrm{TiO}_{2} \mathrm{NF}$ 
A

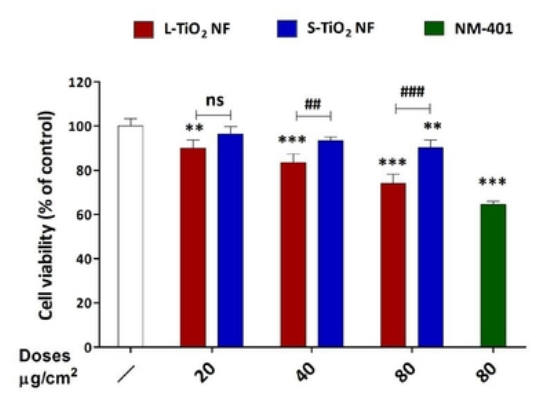

B

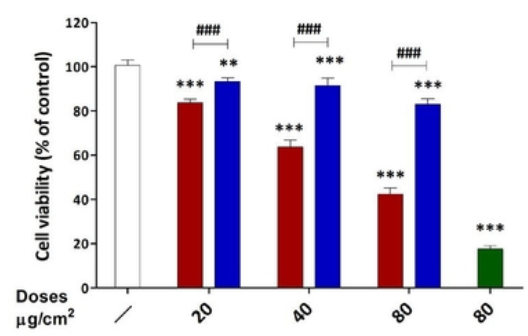

C

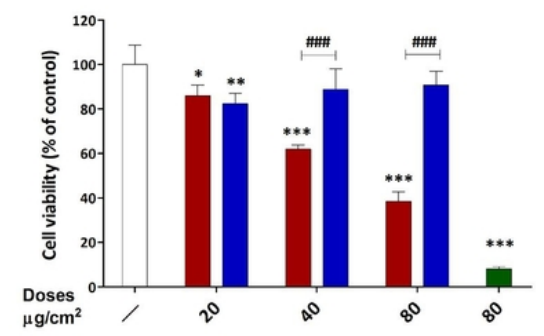

D

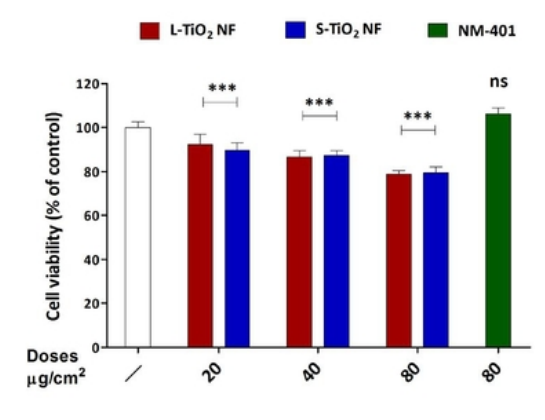

E

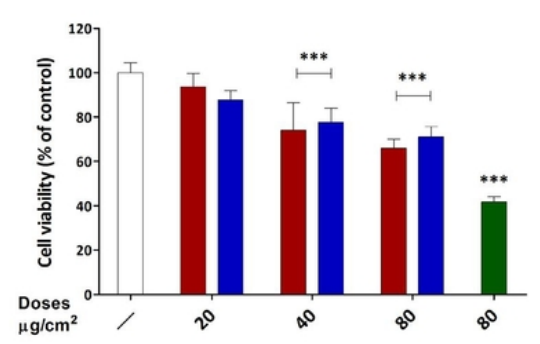

$\mathbf{F}$

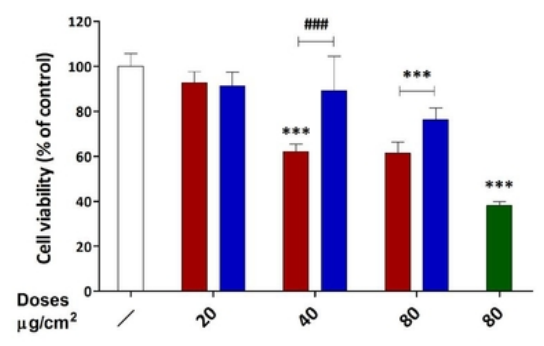

Figure 1. Effect of $\mathrm{TiO}_{2}$ nanofibers on cell viability. $A 549(A, C, E)$ and $16 \mathrm{HBE}$ cells $(B, D, F)$ were exposed for up to $72 \mathrm{~h}$ to the indicated doses of long (L-) or short (S-) $\mathrm{TiO}_{2} \mathrm{NF}$ or to the benchmark material NM-401.

Cell viability was assessed with the resazurin assay at $24,48,72 \mathrm{~h}$. Data are means \pm S.D of six independent determinations. $* * p<0.01, * * * p<0.001 \mathrm{vs}$. control (untreated cultures), as assessed with one-way ANOVA; \#\# $\mathrm{p}<0.01$, \#\#\# $\mathrm{p}<0.001$ between $\mathrm{L}$ - and $\mathrm{S}-\mathrm{TiO}_{2} \mathrm{NF}$, as assessed with two-tail t-test for unpaired data.

$80 \times 88 \mathrm{~mm}(300 \times 300 \mathrm{DPI})$ 


\section{A}

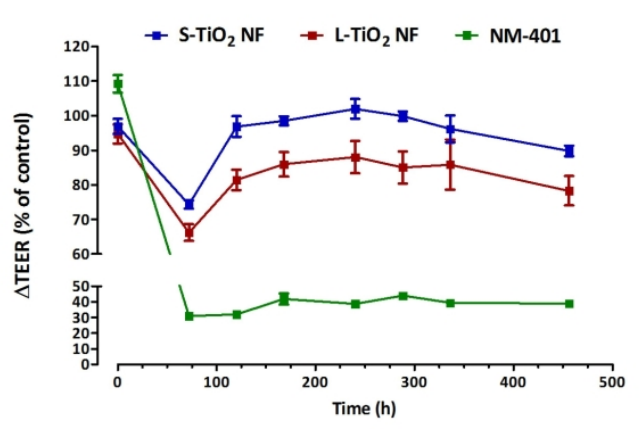

B
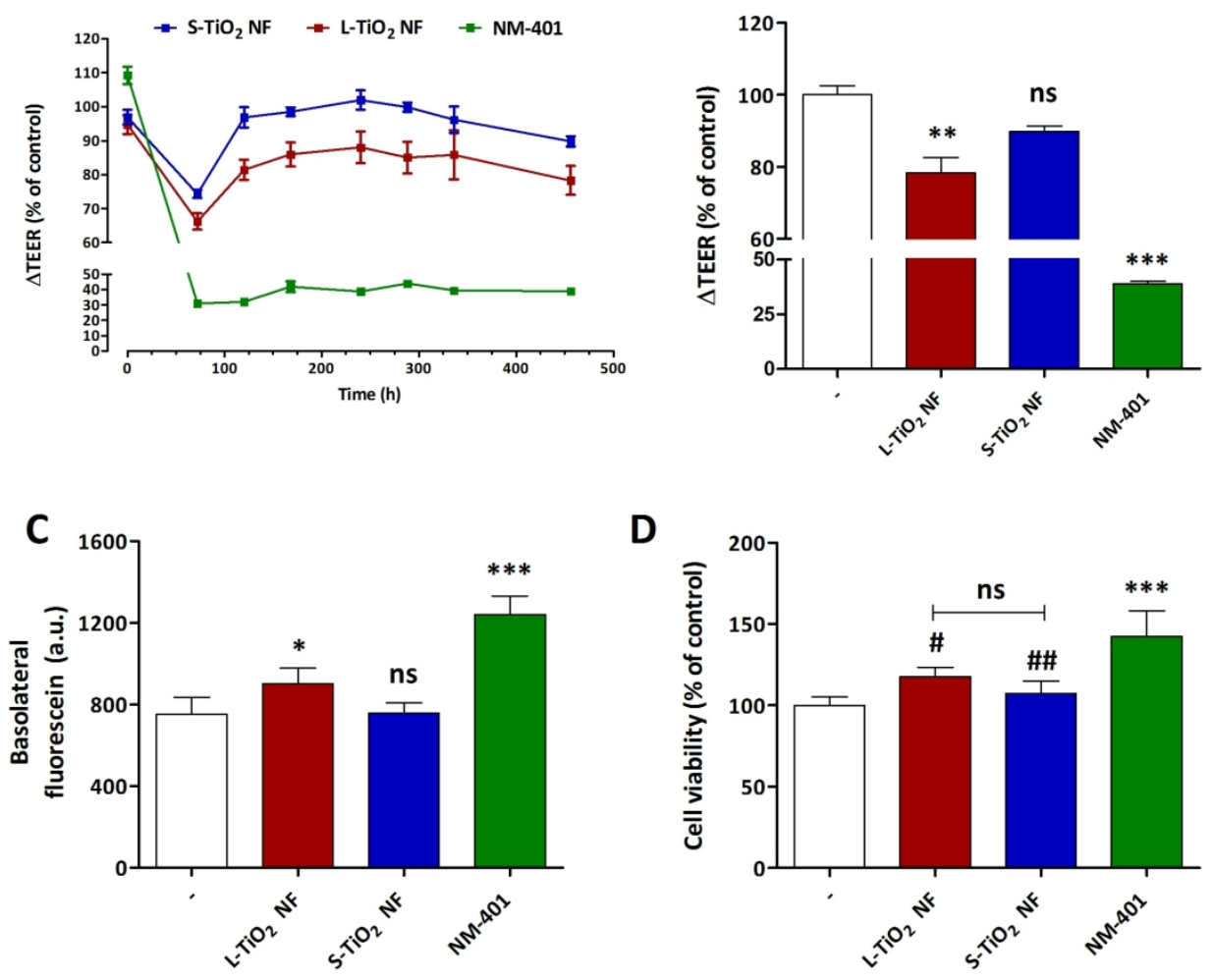

\section{D}

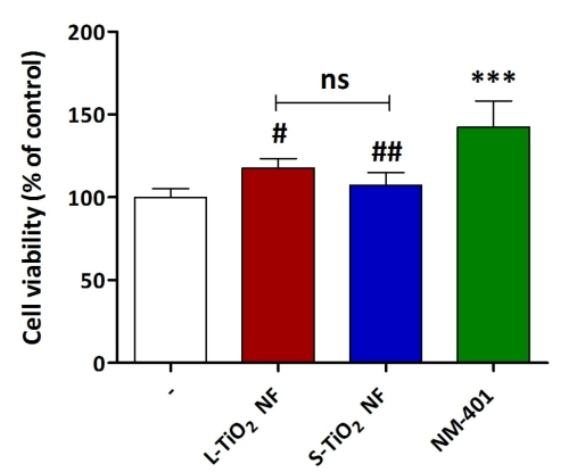

Figure 2. Effect of $\mathrm{TiO}_{2}$ nanofibers on the barrier integrity of human bronchial cell monolayers. $16 \mathrm{HBE}$ airway epithelial cells were cultured on membrane filters and, once reached confluence, $\mathrm{L}-$ or $\mathrm{S}-\mathrm{TiO}_{2} \mathrm{NF}$ were added to the apical chamber at the dose of $80 \mu \mathrm{g} / \mathrm{cm}^{2}$. The Trans-Epithelial Electrical Resistance (TEER) was then measured up to 19d of treatment (A). NM-401 MWCNT, used as benchmark material, were added to other monolayers in parallel. At the end of the experiment TEER (B), fluorescein permeability (C) and cell viability (D) were measured in the same monolayers. Data are means \pm S.D of 4 independent determinations. $* \mathrm{p}<0.05, * * \mathrm{p}<0.01, * * * \mathrm{p}<0.001, \mathrm{~ns}$, not significant vs. control, untreated cultures; $\# \mathrm{p}<0.05, \# \# \mathrm{p}<0.01$ vs. monolayers treated with NM-401 MWCNT.

$$
199 \times 172 \mathrm{~mm}(300 \times 300 \text { DPI) }
$$


Figure 3. At the end of the experiment shown in Figure 2, cell monolayers, kept adherent to the filters, were fixed and immunostained for claudin-7 (red) and ZO-1 (green). DRAQ5 (blue) was used to stain nuclei. (A), After the staining procedure, filters were trimmed from the transwells, laid down and mounted on the coverslip for observation. Control, untreated monolayers; (B) monolayers treated for $19 \mathrm{~d}$ with $\mathrm{L}-\mathrm{TiO}_{2} \mathrm{NF}(80$ $\left.\mu \mathrm{g} / \mathrm{cm}^{2}\right)$; (C) monolayers treated for $19 \mathrm{~d}$ with S- $\mathrm{TiO}_{2} \mathrm{NF}\left(80 \mu \mathrm{g} / \mathrm{cm}^{2}\right)$. For each condition, a single horizontal confocal section of a representative field is shown, with orthogonal projections. Areas where signals are not detected are due to changes in observation plan in correspondence of filter deformations. Arrows, cells with gross claudin-7 delocalization. The experiment has been performed twice with similar results. Bar $=20 \mu \mathrm{m}$.

$99 \times 350 \mathrm{~mm}(300 \times 300 \mathrm{DPI})$ 

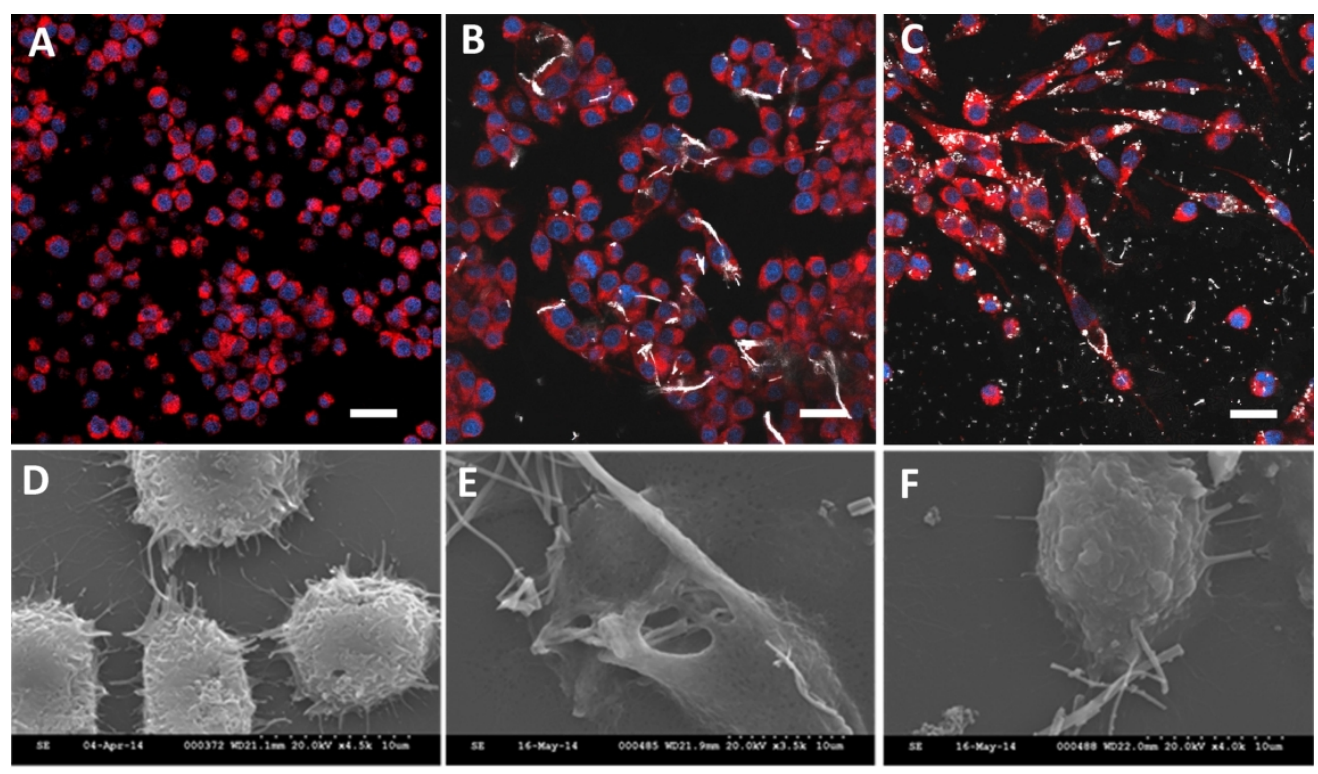

Figure 4. Characterization of nanofiber internalization by Raw264.7 macrophages. Macrophage were seeded on coverslips and, after $24 \mathrm{~h}$, exposed for $24 \mathrm{~h}$ to $\mathrm{L}-\mathrm{TiO}_{2} \mathrm{NF}(\mathrm{B}, \mathrm{E})$ or S-TiO $2 \mathrm{NF}(\mathrm{C}, \mathrm{F})$, both at a dose of 10 $\mu \mathrm{g} / \mathrm{cm}_{2}$, or incubated in control medium $(A, D)$. Cells were then labelled, fixed, mounted and observed in confocal microscopy (A-C, see Methods) Single-plan horizontal sections of representative fields are shown where $\mathrm{TiO}_{2} \mathrm{NF}$ are pseudo-colored in white, the cytoplasm in red and nuclei in blue. For SEM, monolayers were fixed and dehydrated before being mounted (D-F, see Methods). Bars, $20 \mu \mathrm{m}(A, B)$ or $10 \mu \mathrm{m}(C, D)$.

$180 \times 104 \mathrm{~mm}(300 \times 300 \mathrm{DPI})$ 
A

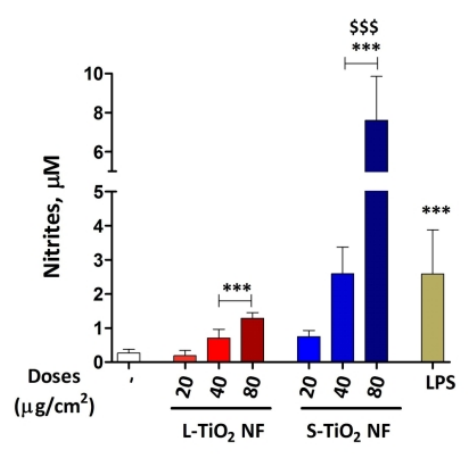

C

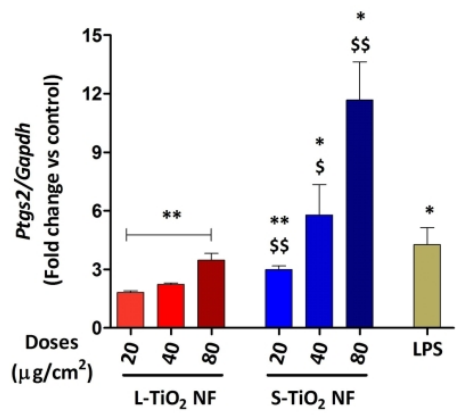

E

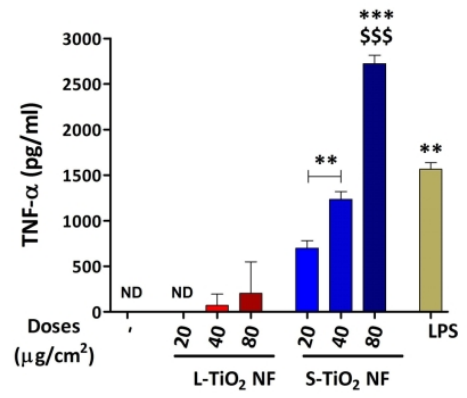

B

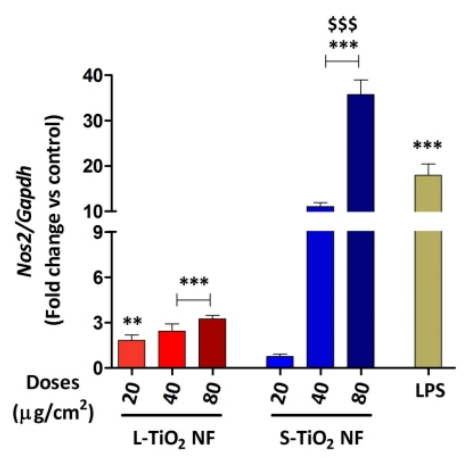

D

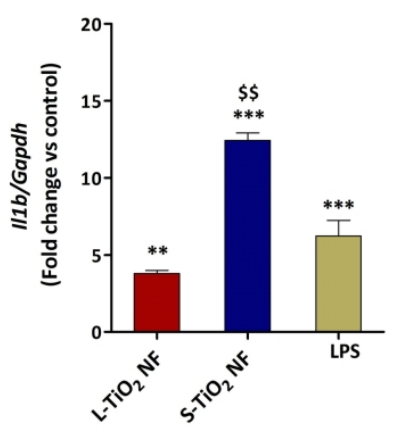

$\mathbf{F}$

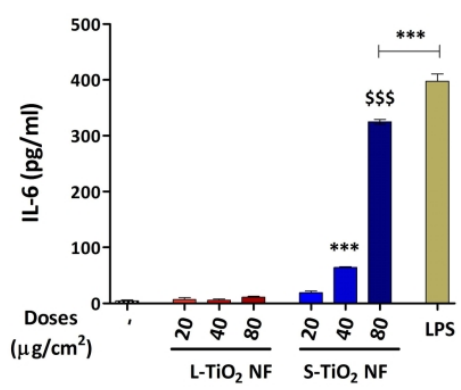

Figure 5. Comparative effects of long and short $\mathrm{TiO}_{2} \mathrm{NF}$ on the expression of pro-inflammatory markers in Raw 264.7 cells. Macrophages were treated with $\mathrm{L}-\mathrm{TiO}_{2} \mathrm{NF}$ or S- $\mathrm{TiO}_{2} \mathrm{NF}$ at the indicated doses or with 10 $\mathrm{ng} / \mathrm{ml}$ of LPS as a positive control and several inflammatory markers were assessed. (A,B,C) After $24 \mathrm{~h}$ of treatment at the indicated doses of NF, medium nitrite concentration (A), Nos2 expression (B) or Ptgs2 expression (C) were assessed. (D) At the same experimental time, the effects of NF (at the dose of 80 $\mu \mathrm{g} / \mathrm{cm}^{2}$ ) on the expression of $I / 1 b$ were assessed. $(E, F)$ After $48 \mathrm{~h}$ of treatment, the levels of TNF- $a$ and IL- 6 were determined in the extracellular medium. Data are means \pm S.D of $3(B-F)$ or 4 (A) independent determinations. $* p<0.05, * * p<0.01, * * * p<0.001$ vs. control, untreated cultures; $\$ \$ p<0.01, \$ \$ \$ p$

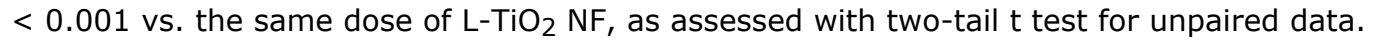




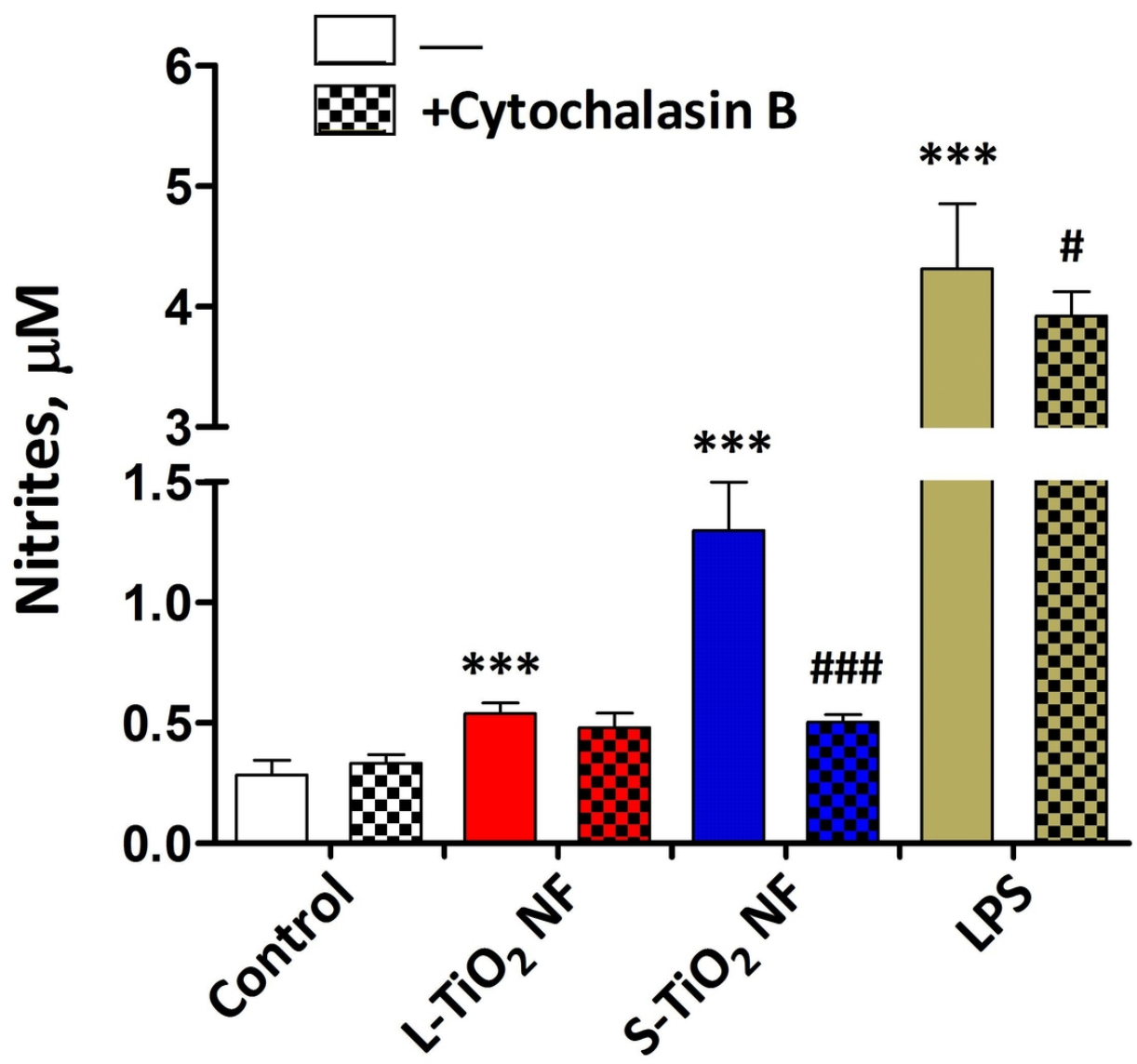

Figure 6. Role of $\mathrm{TiO}_{2}$ nanofiber internalization in NO production in Raw 264.7 cells. Nitrite concentration was measured in the culture medium of macrophages exposed for $48 \mathrm{~h}$ to $\mathrm{L}-\mathrm{TiO}_{2} \mathrm{NF}$ or S-TiO $\mathrm{NF}(40$ $\left.\mu \mathrm{g} / \mathrm{cm}^{2}\right)$ or to LPS $(10 \mathrm{ng} / \mathrm{ml})$ with or without cytochalasin B $(5 \mu \mathrm{g} / \mathrm{ml})$. Data are means \pm SD of 8 independent determinations in two experiments. $* * * \mathrm{p}<0.001$ vs. control, untreated cultures; \# $\mathrm{p}<0.05$, \#\# \# $\mathrm{p}<0.001$ vs. the same condition without cytochalasin B.

$101 \times 96 \mathrm{~mm}(300 \times 300$ DPI $)$ 

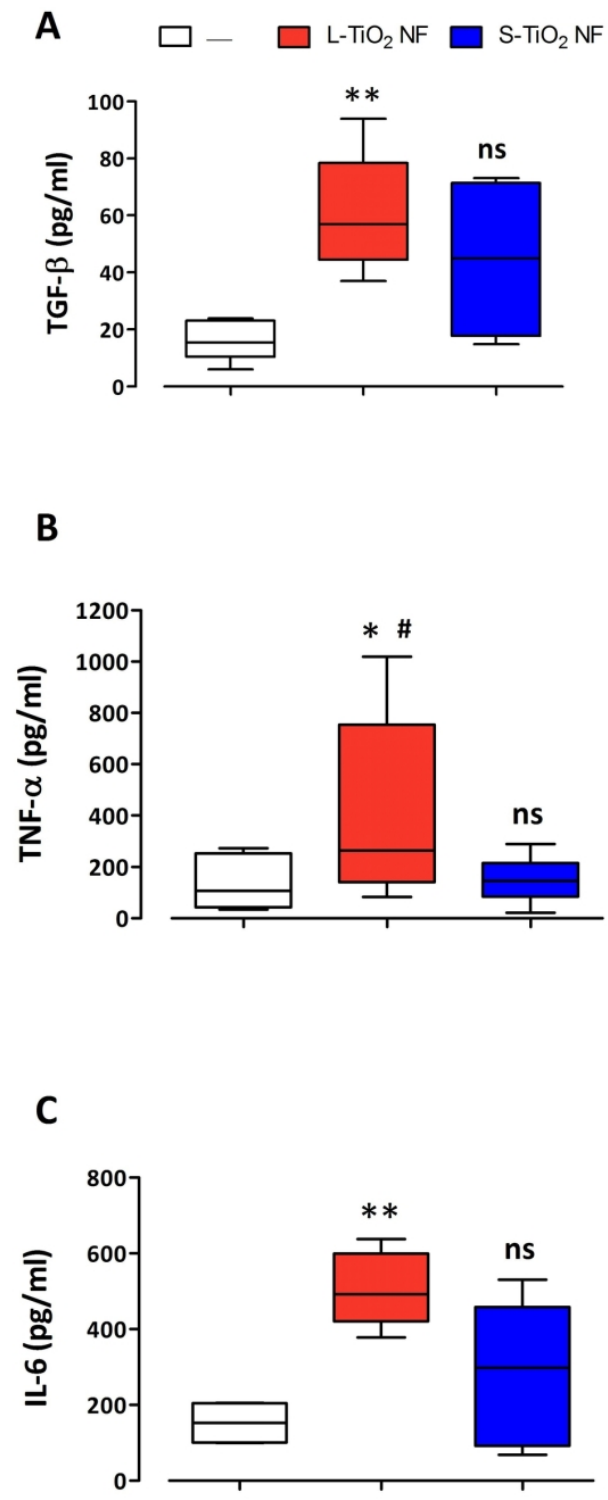

Figure 7. $\mathrm{BAL}$ cytokines in $\mathrm{C} 57 \mathrm{BL} / 6$ mice exposed to $\mathrm{TiO}_{2} \mathrm{NF}$. C57BL/6 mice were exposed through pharingeal aspiration to $40 \mu \mathrm{g}$ of $\mathrm{L}$ - (red bars) or $\mathrm{S}-\mathrm{TiO}_{2} \mathrm{NF}$ (blue bars) suspended in sterile water containing $1.4 \mathrm{mg} / \mathrm{ml}$ BSA or in vehicle alone (control, empty bars). After 14d, BAL were collected and TGF$\beta$, TNF- $a$ and IL- 6 were measured with ELISA. $* p<0.05, * * p<0.01$ vs. control; ns, not significant vs. control; \# $\mathrm{p}<0.05$ vs. S-TiO 2 NF, as assessed with ANOVA. $91 \times 205 \mathrm{~mm}(300 \times 300 \mathrm{DPI})$ 


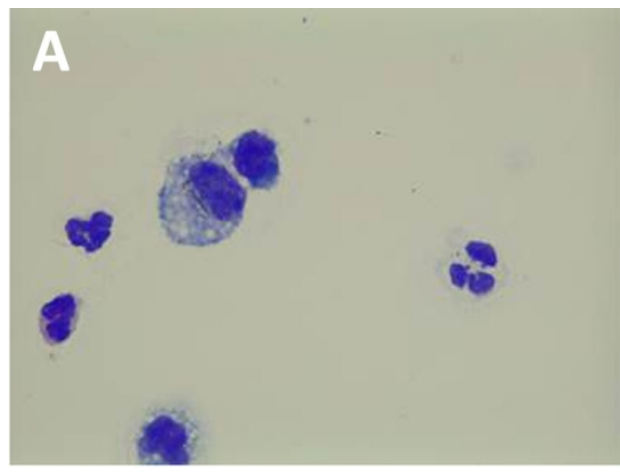

\section{C}
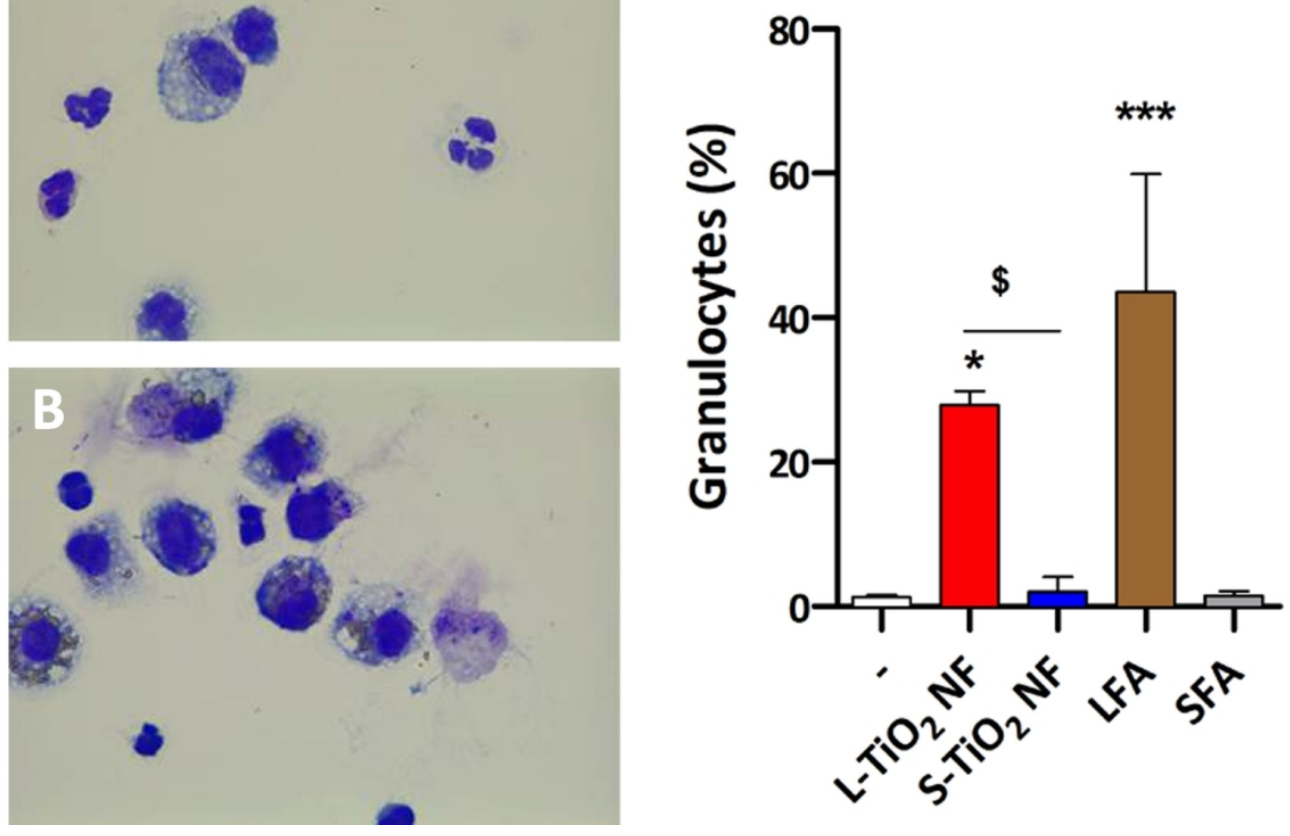

Figure 8. Peritoneal lavage granulocytes in $\mathrm{C} 57 \mathrm{BL} / 6$ mice exposed to $\mathrm{TiO}_{2} \mathrm{NF}$ or long fibre (LFA) or short fibre (SFA) amosite asbestos. C57BL/6 mice were exposed through intra-peritoneal injection to $\mathrm{L}_{-} \mathrm{TiO}_{2} \mathrm{NF}$, S-TiO2 NF, long fibre amosite, short fibre amosite asbestos (50 $\mu \mathrm{g}$ of each material) suspended in sterile water containing $0.5 \%$ BSA or to vehicle alone. After $24 \mathrm{~h}$, the peritoneal cavity was lavaged and cells determined via a differential cell count. (A) $\mathrm{L}^{-\mathrm{TiO}_{2}}$ (chevron) containing macrophage. (B). Several macrophages containing $\mathrm{S}-\mathrm{TiO}_{2}$ (chevrons). (C) Percentage granulocytes in the peritoneal fluid *p $<0.05$, $* * * \mathrm{p}<0.001$ vs. control; $\$ \mathrm{p}<0.05$ vs. $\mathrm{S}-\mathrm{TiO}_{2} \mathrm{NF}$, as assessed with ANOVA $(\mathrm{n}=3)$. 
Figure 9. Differential outcomes of exposure to long and shortened $\mathrm{TiO}_{2}$ nanofibers. $94 \times 90 \mathrm{~mm}(300 \times 300$ DPI $)$

Macrophages not activated

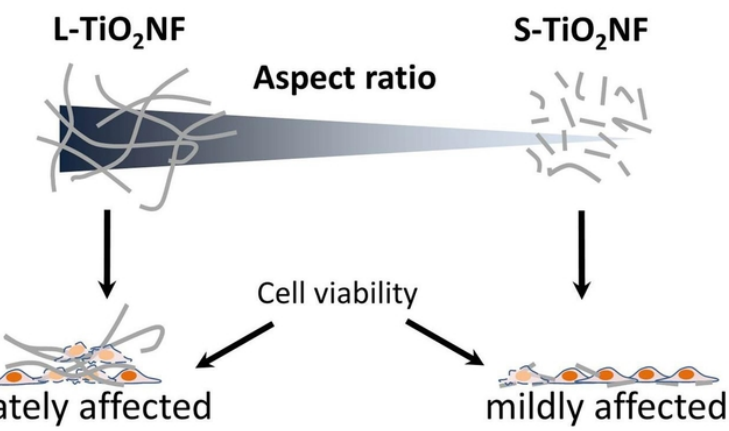

moderately affected

Trans-epithelial permeability

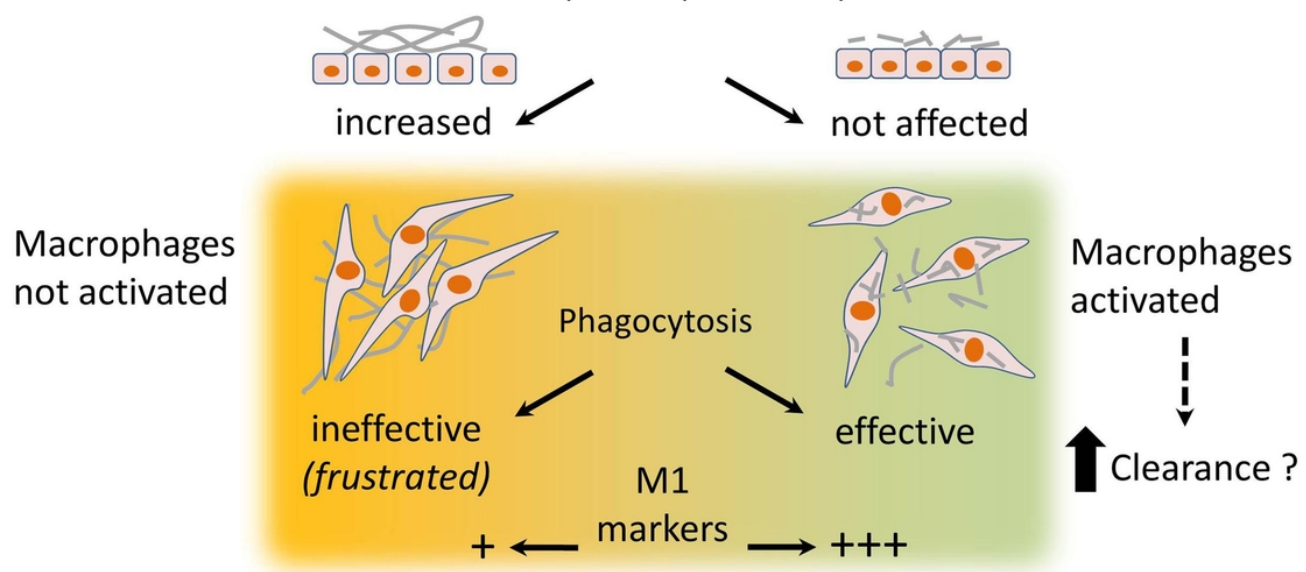

